\title{
Stratejik Pazarlama Performansını Belirlemeye Yönelik Bir Model Önerisi ${ }^{1}$
}

\author{
A Model Proposal for Determining Strategic Marketing Performance
}

\author{
Şeyma Nur AYDIN* \\ Ismail GÖKDENIZ**
}

$\ddot{O} Z$

\begin{abstract}
Küreselleşme ile birlikte teknolojide yaşanan gelişmeler, rekabetin yoğunlaşması, insan ihtiyaçlarının artması ve çeşitlenmesi pazarlama faaliyetlerinde pek çok gelişmeye neden olurken, pazarlamanın kontrolünü de zorunlu hale getirmiştir. Pazarlama kontrolü için performans ölçütlerinin seçimi son derece önemlidir. Bu nedenle pazarlama yöneticileri faaliyet gösterilen sektör ve işletme türüne göre doğru performans ölçütlerini belirlemeye çallşırlar. Bazı ölçütler sektöre ve işletmeye uymamasına rağmen sadece kantitatif verilere dayanması gibi sebeplerle yine de tercih edilmektedir. Ancak ölçüt seçiminde gerçekçi davranmak gerekir. Kolay ölçülmesinden dolayı sadece kantitatif verilerden yararlanmak geleceğe yönelik doğru bir bilgi sunmayabilir. Bu nedenle pazarlama performansinın belirlenmesinde kantitatif ve kalitatif verilerin birlikte değerlendirildiği bir yaklaşım izlemek daha uygun olabilir. Bu çalışmada pazarlama performansının belirlenmesi için hem finansal hem de finansal olmayan ölçütlerin bir arada yer aldı̆̆ hiyerarşik bir model önerilmiştir. Çalışmada kullanılan pazarlama performans ölçütleri literatür taraması ve konuyla ilgili bilimsel çalışmalara sahip olan akademisyenlerin görüşleri sonucunda şekillenmiştir. Bununla birlikte, çalışmaya konu olan işletmenin pazarlama performansını ölçerken baz aldı̆̆ pazarlama stratejileri öğrenilmiştir. Değerlendirme, pazarlama yöneticisinin bu stratejiler doğrultusunda performans ölçütlerine verdiği puanlama ile gerçekleşmiştir. Performans ölçütlerinin ă̆ırlığ Analitik Hiyerarşi Prosesi yöntemi ile hesaplanmış ve hiyerarşik model oluşturulmuştur. Çalışmanın son aşamasında ise işletmenin pazarlama performans ölçütlerinin mevcut durumu hakkında genel değerlendirme yapılmıştır.
\end{abstract}

\section{ANAHTAR KELIMELER}

Strateji, Stratejik Pazarlama, Pazarlama Performansl, Pazarlama Performans Ölçütleri, Analitik Hiyerarşi Prosesi

\begin{abstract}
With globalization, developments in technology, intensification of competition, increase and diversification of human needs caused many improvements in marketing activities and made it necessary to control marketing. The choice of performance criteria for marketing control is extremely important. Therefore, marketing managers try to determine the correct performance criteria according to the sector and type of business in which they operate. Although some criteria do not fit the sector and the enterprise, they are still preferred because of the fact that they are based on quantitative data. However, the selection of criteria should be realistic. Because of its easy measurement, only quantitative data may not provide accurate information for the future. Therefore, it may be more appropriate to follow an approach that evaluates quantitative and qualitative data together in determining marketing performance. In this study, a hierarchical model combining both financial and non-financial criteria is proposed to determine marketing performance. The marketing performance criteria used in the study were shaped as a result of the literature review and the opinions of the academicians who have scientific studies on the subject. In addition, the marketing strategies that are used to measure the marketing performance of the business subject are learned. The evaluation is based on the rating given by the marketing manager to the performance criteria determined in line with these strategies. The weight of the performance criteria was calculated by the Analytic Hierarchy Process method and a hierarchical model was formed. In the last stage of the study, an evaluation was made about the current status of the marketing performance criteria.
\end{abstract}

\section{KEYWORDS}

Strategy, Strategic Marketing, Marketing Performance, Marketing Performance Metrics, Analytic Hierarchy Process

\begin{tabular}{|c|c|c|}
\hline & $\begin{array}{l}\text { Makale Geliş Tarihi / Submission Date } \\
12.02 .2020\end{array}$ & $\begin{array}{l}\text { Makale Kabul Tarihi / Date of Acceptance } \\
\text { 05.04.2020 }\end{array}$ \\
\hline Attf & \multicolumn{2}{|c|}{$\begin{array}{l}\text { Aydın, Ş.N. ve Gökdeniz, İ. (2020). Stratejik Pazarlama Performansını Belirlemeye Yönelik Bir Model Önerisi. Selçuk } \\
\text { Üniversitesi Sosyal Bilimler Meslek Yüksekokulu Dergisi, } 23 \text { (1), 372-393. }\end{array}$} \\
\hline
\end{tabular}

\footnotetext{
${ }^{1}$ Bu çalıșma Şeyma Nur Aydın tarafindan hazırlanan ve Doç. Dr. İsmail Gökdeniz tarafindan yönetilen yüksek lisans tezinden türetilmiștir. * Bilim Uzmanı, Kırıkkale Üniversitesi Sosyal Bilimler Enstitüsü I̦şletme Ana Bilim Dalı Doktora Öğrencisi, seymanuraydin125@ gmail.com, ORCID: 0000-0002-9553-5117

*** Doç. Dr., Kırıkkale Üniversitesi İktisadi ve İdari Bilimler Fakültesi Öğretim Üyesi, isgokdeniz@ gmail.com, ORCID: 0000-0003-4342-0200
} 


\section{GİRIŞ}

Stratejik pazarlama planının en son aşaması olan pazarlama performansının değerlendirilmesi süreci, son y1llarda pazarlama faaliyetlerinde meydana gelen gelişmeler ile birlikte, hem akademisyenler hem de üst düzey pazarlama yöneticileri açısından önemli bir konu haline gelmiştir.

Pazarlama performansının ölçülmesinde temel problem, ölçümü gerçekleştirecek en iyi ölçütlerin ve uygulamaların belirlenmesindedir (Ambler, 2000: 59). Literatürde bu konuyla ilgili birçok teorik ve kavramsal çalı̧̧ma olmasına rağmen, performans ölçümünün gerçekleşmesinde kullanılacak ölçütlerin neler olduğuna dair yapılan çalışma sayısı oldukça azdır (Hacıoğlu, 2010: 6). Pazarlama performansını tek bir ölçüt ile değerlendirmek mümkün olmayacağı için, pazarlama yöneticileri performans değerlendirmede birçok ölçüt kullanırlar (Hacıoğlu, 2012: 70). Bu sebeple ölçüt seçiminde dikkatli olmak gerekir. Bazı ölçütler yaygın kullanılması ve kolay ölçülmesi nedeniyle sektör, ürün ve pazar için yeterli olmamasına rağmen yinede tercih edilir (Torlak ve Altunışık, 2012: 87-88). Bu durum pazarlama performansını değerlendirmede gerçek sonuçların ortaya çıkmamasına sebebiyet verebilir.

Pazarlama performansının değerlendirilmesinde genellikle ilk sırada finansal ölçütler yer almaktadır. Ancak bu ölçütler geçmiş ile ilgili eksiksiz bilgi sunarken gelecek hakkında tam anlamıyla fikir vermezler. Bu yüzden finansal ölçütlerin, bilgi çağının iş gerçekleriyle uyumlu olmadığı söylenebilir (Cop ve Bekmezci, 2008: 256). Performans değerlendirmede sadece finansal ölçütlerin kullanılması işletmelerin uzun vadede karlı yatırımlar yapmalarını engelleyebileceği gibi, mevcut durumun yanlış değerlendirilmesine de sebep olabilir (Güner, 2006: 2). Dolayısıyla pazarlama performans ölçümü finansal ölçütlerden, müşteri değerine yönelik finansal olmayan ölçütlere kadar geniş bir yelpazede ele alınmalıdır. Zaten en iyi ölçüm işletme stratejileri de göz önünde bulundurularak bu ölçütlerin birlikte değerlendirilmesi ile gerçekleşecektir (Clark, 2001: 367).

Clark (1999) pazarlama performansının tarihini anlattığı makalesinde, 1980'li yıllarda finansal olmayan ölçütlerle de ölçüm yapıldığını ve son 10 yılda müşteri memnuniyeti, müşteri sadakati ve marka değeri gibi ölçütlerinde önemli hale geldiğini ifade etmiştir. Pazarlama performans ölçütlerinde değişim olduğunu ve bunun finansal ölçütlerden finansal olmayan ölçütlere, çıktıdan girdiye, tek boyutlu ölçütlerden çok boyutlu ölçütlere doğru gerçekleştiğini bildirmiştir.

Ambler ve Kokkinaki (1997) yedi önemli pazarlama ve strateji dergisinde yer alan performans ölçütlerini incelemişler ve araştırmada pazarlama performansını ölçmek için en çok kullanılan ölçütlerin satışlar, pazar payı, kar payı gibi finansal ölçütler olduğunu ve bunları marka tercihi / satın alma niyeti gibi finansal olmayan ölçütlerin takip ettiğini bulmuşlardır. Ambler ve Xiucun (2003) Çin ve İngiltere arasında pazarlama performans ölçütlerini karşılaştırmak için bir çalışma yapmışlar ve İngiltere'de önem derecesi yüksek olan ölçütlerin finansal ölçütler olduğunu bulurken, Çin'de ise müşteri ölçütlerinin daha önemli olduğu kanısına varmışlardır. Ambler ve diğ. (2004), İngiltere'de yapmış oldukları bir çalışmada pazarlama performans ölçümünde kullanılan 15 ölçütü kullanılma sıklığı açısından önem derecelerine göre sıralamış, karlılık ve satışlar gibi finansal ölçütlerin listenin en başında yer aldığı sonucuna varmışlardır.

Eusebio ve diğ. (2006) İspanya' da turizm ve üretim sektörlerinde faaliyet gösteren 500 işletmede pazarlama performans ölçütlerinin önem düzeyini belirlemek için bir karşılaştırma yapmışlar ve araştırmada pazarlama performansını Kokkinaki ve Ambler (1999) tarafından oluşturulan altı kategoride ele almışlardır. Araştırma sonucunda turizm işletmelerinde tüketici davranışları kategorisinde yer alan müşteri memnuniyeti ve müşteri sadakati ölçütlerinin önem düzeyinin daha yüksek olduğu, üretim işletmelerinde ise ciro, katkı payı ve karlılık gibi finansal ölçütlerin önem düzeyinin daha yüksek olduğu sonucuna ulaşmışlardır. Sampaio ve diğg. (2011) Brezilyalı yöneticilerin pazarlama performansı ölçütlerini nasıl kullandıklarını ve hangilerinin ölçüm için en uygun olduğunu göstermek için yaptıkları çalışmada, müşteri memnuniyeti, toplam müşteri sayısı ve şikayet sayısı gibi müşteri ölçütlerinin en çok kullanılan ölçütler olduğu sonucunu bulmuşlardır.

Literatür incelediğinde (Ambler, 2000; Ambler ve diğ., 2004; Barwise ve Farley, 2004; Smith ve Madden, 2005; Çetin ve diğ., 2006; Gronholdt ve Martensen, 2006; Hooper, 2006; ; Uzkurt ve diğ., 2006; Toksar1 ve Mürütsoy, 2007; Farley ve diğ., 2008; Zahay ve Griffin, 2010; Sampaio ve diğ., 2011; Çatı ve diğ., 2012; Bulut, 2013; Gaskill ve Winzar, 2013; Hacioğlu ve Gök, 2013; Mintz ve Currim, 2013; Elisa ve Gordini, 2014; Tüfekçi ve Tüfekçi, 2014; Milichovsky ve Simberova, 2015; Yeşildağ, 2016) performans ölçümünde kullanılacak çok sayıda pazarlama ölçütü olduğu ve bu nedenle akademisyenlerin farklı ölçütler ile değerlendirme yaptığı görülmüştür. Yani pazarlama performansını ölçmede kullanılacak ölçütler konusunda bir fikir birliği söz konusu değildir. Bu nedenle bu çalışmada daha önceki çalışmalardan farklı olarak çalışmaya konu olan işletmenin pazarlama stratejilerinin de dahil edildiği, finansal, müşteri, süreç, ürün ve fiyat ölçütlerinin birlikte değerlendirildiği hiyerarşik bir model önerilmektedir. Ayrıca çok kriterli karar verme 
tekniklerinden olan Analitik Hiyerarşi Prosesi yöntemi incelenen literatürde daha önce kullanılmamıştır. Çalışmanın bu yönüyle de literatüre katkısının olacağı düşünülmektedir.

\section{PAZARLAMA PERFORMANSI VE PERFORMANS ÖLÇÜTLERİ}

$\mathrm{Bu}$ başlık altında pazarlama performansı ve ölçme gerçekleşirken kullanılan pazarlama performans ölçütlerinden bahsedilmiştir.

\subsection{Pazarlama Performansı}

Günümüzde tüketicilerin istek ve ihtiyaçları her geçen gün değişmektedir. Tüketicilerin istek ve ihtiyaçlarında meydana gelen bu değişim pazarı da değişime sürüklemektedir. Bu nedenle işletmeler pazardaki dinamik yapıyı takip etmenin ve talebi fazla olan mal ve hizmeti üretme çabası içindedir. İşletmelerin üretilecek mal ya da sunulacak hizmetle ilgili karar almasını sağlayan birim pazarlama fonksiyonudur. Pazarlama fonksiyonu, işletmeler için hayati önem taşıyan bir birimdir. Çünkü pazarlama faaliyetleri, işletmelerin başarılı olmasında kilit bir rol üstlenir ve işletmenin itici gücü olarak görev yapar. Bir işletmenin diğer faaliyetleri ne kadar etkili olarak yürütülse de, mal ve hizmetler tüketiciler için uygun değilse veya herhangi bir nedenden dolayı satış gerçekleşmiyorsa başarısızlık kaçınılmaz olacaktır (Mucuk, 2014: 232).

Pazarlama performansı; işletmeler için bu kadar önem arz eden pazarlama biriminin ve pazarlama faaliyetlerinin başarısını ifade etmektedir. Bu noktada pazar (firma) performansı ile pazarlama performansı arasında fark olduğunu söylemek gerekir. Pazar (firma) performansı, işletmelerin pazardaki başarısını bir bütün olarak ifade ederken, pazarlama performansı, bu başarıya etki eden pazarlama faaliyetlerinin başarısı olarak değerlendirilmektedir (Çalık ve diğ., 2013: 143). Pazarlama çabalarını ekonomik açıdan bir "fayda" oluşturma faaliyeti olarak ele aldığımızda pazarlama performansının işletmeler için önemi daha da artmaktadır (Günay ve Ayyıldız, 2017: 114). Pazarlama performans ölçümü, özellikle pazarlama maliyetlerinin fazla olduğu işletmelerde yöneticiler için son derece önemli bir konu haline gelmiştir. Ölçüm sistemi, planlama ve kontrol sistemini desteklemek amacıyla bütün işletmenin genel performans ölçüm sistemi ile uyumlu olmalıdır. Bir işletmenin pazarlama performansının iyileştirilmesi, müşteri istek ve tercihlerini doğru tespit etmeye ve mal ve hizmetleri rakip işletmelerden daha iyi bir şekilde sunmaya bağlıdır (Çetin vd., 2006: 48).

Pazarlama yöneticileri, pazarlamanın hesap verebilirliği ve güvenilirlik sorunlarıyla sıkça karşılaşmaktadırlar (Gao, 2010: 25). Pazarlamanın bu sorumluluk eksikliği pazarlamacıların güvenirliğini olumsuz yönde etkilerken, pazarlamanın varlığını tehdit ederek, işletme içerisindeki konumunu kaybetmesine neden olmaktadır (Rust ve diğ., 2004: 76). Bu nedenle tamamlanmamış bir pazarlama performans ölçüm sisteminin, hiç olmamasından daha iyi olduğu söylenebilir (Brooks ve Simkin, 2011:3). Zaten pazarlama girdileri ile çıtıları arasındaki ilişkinin belirlenmesi ve pazarlama faaliyetlerinin etkinliğinin ölçülmesi işletmeler açısından giderek zorunlu bir hal almaktadır. Çünkü firma performans artışının sağlanması için pazarlama faaliyetlerinde hangi değişikliklerin yapılması gerektiği önemli bir konudur (Çıtak, 2015: 50).

Pazarlama performansının ölçülmesi işletmeler için zor ve zaman alıcıdır. Bu nedenle yöneticileri pazarlama faaliyetleri açısından değerlendirme yapmaya ikna etmek için zorlayıcı araştırmalara ihtiyaç duyulmaktadır (Clark ve Ambler, 2001: 13). Yöneticilerin pazarlama faaliyetlerinin işletme performansına yaptığı katkıyı ölçmedeki başarısızlıkları, pazarlamanın işletme içerisindeki öneminin belirlenememesine neden olacaktır. Bundan dolayı pazarlama performansının ölçülmesi konusunda pazarlama fonksiyonu, artan bir baskı ile karşılaşmaktadır (Hacıoğlu, 2012: 59).

Tüm bunlar dikkate alındığında pazarlama performans ölçümünün işletmeler açısından önemini aşağıdaki gibi sıralamak mümkündür. Pazarlama performans ölçümü;

$>$ Pazarlama faaliyetlerinin hesap verilebilirliğini sağlamaktadır.

$>$ Pazarlama yöneticilerine olan güveni artırmaktadır.

> Pazarlama biriminin işletme içerisindeki önemini ve konumunu netleştirmektedir.

$>$ Pazarlama faaliyetlerinde hangi değişikliklerin yapılması gerektiği, hangilerine devam edilmesi konusunda yöneticilere fikir vermektedir.

Ayrıca pazarlama performansının ölçülmesi firma performansı açısından da önem arz etmektedir. Çünkü, pazarlama performansını ölçebilme becerisine sahip olan firmaların, performans raporlaması ile eksiklikleri tespit etmesi ve bunu gidermeye çalışması genel firma performansında da bir iyileşmeye yol açacaktır (O’Sullivan ve diğ., 2009: 856).

\subsection{Pazarlama Performansının Belirlenmesine Yönelik Ölçütler}

İşletmelerin değişen pazar koşullarına uyum sağlayabilmek için, performans ölçütlerini belirlemeleri ve bu doğrultuda faaliyetlerini periyodik olarak değerlendirmeleri gerekir. Çünkü rakipleri karşısında güç elde 
etmeleri bu ölçütlerle yapılacak değerlendirmeler 1şığında, gerekli düzenlemeleri yapmaları ile mümkün olmaktadir (Kabadayı, 2002: 61).

Pazarlama faaliyetlerinin kontrolü için öncelikle değerlendirme kriterlerinin belirlenmesi, daha sonra da ölçme işleminin gerçekleşmesi gerekir. Belirlenen ölçme ve değerlendirme standartlarına performans ölçütleri denilir (Günay ve Ayyıldız, 2017: 117). Performans ölçütleri, faaliyetler hakkında gerekli bilgileri sunarken, yöneticilerin karar almalarına, planlama yapmalarına, kontrol gerçekleştirmelerine, amaçlara uygun stratejiler belirlemelerine ve iyileştirici düzenlemeler yapmalarına yardımcı olmaktadır. Ayrıca iyileştirmenin sağlıklı bir şekilde gerçekleşmesinde de önemi büyüktür (Kabaday1, 2002: 74). Yöneticiler vizyon, misyon ve stratejiler 1şığında amaç ve hedeflerini belirleyerek ölçütlere karar verirler. Ancak bu doğrultuda daha iyi hizmet sunma çabasında olan ve sonuçlardan maksimum değer elde etmeyi amaçlayan bir işletmenin varlığından söz edilebilir (Ataman-Akgül, 2004: 74). Performans ölçütlerinin doğru seçilmemesi pek çok gizli maliyeti de beraberinde getirir. Yanlış seçilen performans ölçütleri, yöneticilerin yanlış karar almalarına neden olduğu gibi işletmeleri beklenenin altında sonuçlara da götürmektedir. Ayrıca kaynak israfı ve aşırı yatırım gibi durumları da ortaya çıkarmaktadır (Ertuğrul, 2009: 21).

Pazarlama performansının ölçülmesi, finansal ve finansal olmayan performans kriterlerini birlikte barındıran bir dengeli puan kartı yöntemine uymayı gerektirmektedir (Beukes ve Wyk, 2016: 138). Dengeli puan kartı yöntemi, çok boyutlu performans ölçüm yöntemlerinden biridir. Bunlar, geleneksel performans ölçüm sistemlerinin eksikliklerini gidermek için finansal ölçütlerin yanı sıra finansal olmayan ölçütleri de kullanarak tam bir değerlendirme imkanı sunmaktadır (Yaşar, 2016: 193). Bu nedenle pazarlama performans ölçütleri finansal ve finansal olmayan ölçütler olarak iki grupta incelenmektedir (Hacıoğlu, 2012: 60).

Pazarlama performansının belirlenmesinde genellikle ilk sırada finansal ölçütler yer almaktadır (Clark, 1999: 713; Günay ve Ayyıldız, 2017: 118). Finansal performans ölçütleri ile var olan somut veriler kullanılarak ölçme gerçekleştiğinden daha düşük maliyet ve daha az zaman gerektirmektedir (Bayraktaroğlu ve diğ., 2014: 285-286). Bu nedenle tüm işletmelerin performans değerlendirmede ilk tercihi finansal ölçütlerdir. Karlılık, satışlar, nakit akışı ve pazar payı pazarlama performansının ölçülmesinde sıklıkla kullanılan finansal ölçütlerdendir (Günay ve Ayyıldız, 2017: 118).

Finansal olmayan performans ölçütleri ise, işletmelerin finansal tablolara yansımayan ve sonuçları raporlanamayan performans ölçütleri olarak ifade edilebilir. Özellikle finansal performans ölçütlerinde müşteri değerinin dikkate alınmaması finansal olmayan performans ölçütlerine olan ilgiyi artırmıştır. Çünkü müşteri değerinin dikkate alınmadığı bir performans ölçüm sürecinde işletmelerin doğru kararlar alması mümkün olmamaktadır (Yiğiter, 2011: 2). Pazarlama performansının değerlendirilmesinde en çok kullanılan finansal olmayan ölçütler, müşteri memnuniyeti ve müşteri sadakatidir.

\section{UYGULAMA}

\subsection{Araştırmanın Yöntemi}

$\mathrm{Bu}$ araştırma stratejik pazarlama performansının belirlenmesine yönelik hiyerarşik bir model oluşturmayı amaçlamıştır. Bu nedenle literatür incelemesi ve konuyla ilgili bilimsel çalışmalara sahip akademisyenlerin görüşlerinin alınması ile pazarlama performansının değerlendirilmesinde kullanılan ölçme kriterleri belirlenmiştir. Kriter sayısının fazla olması ve fikir birliğinin olmaması nedeniyle ölçme kriterleri sınıflandırılmıştır. Bununla birlikte üretim sektöründe faaliyet gösteren bir işletmenin pazarlama yöneticisi ile görüşülerek işletmenin vizyonu doğrultusunda belirledikleri pazarlama stratejileri öğrenilmiştir ve performans değerlendirmesi bu stratejilere göre, belirlenmiş olan ölçütlere verilen puanlama ile gerçekleşmiştir. Değerlendirme üretim sektöründe faaliyet gösteren bir işletmenin pazarlama yöneticisi ile gerçekleştiğinden, bu araştırma, çalışma kapsamındaki işletme ile sınırlı kalmıştır.

Çalışmada hiyerarşik bir model oluşturmak amaçlandığı için çok ölçütlü karar verme yöntemlerinden olan “Analitik Hiyerarşi Prosesi” (AHP) yönteminden yararlanılmıştır. AHP, bir kriterin veya bir alternatifin toplam puan içindeki ağırlığını belirlemek için kullanılan, kriterlerin ve alternatiflerin ikili karşılaştırmasına dayanan bir ağırlıklandırma metodudur. Dolayısıyla herhangi bir problemin çözümünde karar vericilerin verecekleri puanlara göre alternatifler ve kriterler arasındaki önem sırasını belirler. Ayrıca nitel kavramların sayısal olarak ifade edilmesinde de oldukça elverişli bir yöntemdir. Bu nedenle çalışmadaki problemin çözümünde AHP yöntemi tercih edilmiştir.

\subsection{Analitik Hiyerarşi Prosesi}

Myers ve Albert'in 1968 y1lında ileri sürdüğü Analitik Hiyerarşi Prosesi yöntemi, daha sonra Saaty tarafindan geliştirilmiş ve karar verme problemlerinin çözümünde önemli bir model haline gelmiştir. AHP, karar hiyerarşisinin oluşturulması ile birlikte, kararı etkileyecek faktörlerin yüzdelik dilimlerini gösteren 
tahmin etme ve karar verme tekniği olarak tanımlanabilir (Yaralığlu, 2001: 131). Karar vermede grupların ya da bireylerin önceliklerini de gözeten, hem nicel hem de nitel değişkenlerin birlikte değerlendirilmesine yarayan bir metottur (Dağdeviren ve diğ., 2004: 132). İkili karşılaştırma matrisi sayesinde kararın verilmesinde etkili olan faktörlerin önem derecelerini ortaya koyarken, karar alternatiflerinin de sıralamasını gerçekleştirir (Ömürbek ve Şimşek, 2014: 306). AHP, karar vericilere karar vermede yardımcı olmak için matris cebiri, öz vektörler ve ikili karşılaştırmalar kullanır. Problemi ana ve alt kriterlere ayırarak hiyerarşik bir formda yapılandırır. Hiyerarşi kurulduktan sonra, karar veren / uzman, ana ve alt kriterlerin önceliklendirilmesine izin verir (Knott ve James, 2003: 88-89). Hiyerarşinin üst kısmında çalışmanın amacı, alt kısmında ise sırasıyla kriterler, alt kriterler ve alternatifler bulunur (Başkaya ve Akar, 2005: 275). AHP'nin hiyerarşik yapısı Şekil 1 'de gösterilmiştir.

Şekil 1. Hiyerarşik Yapı (Wang ve diğ., 2008: 515)

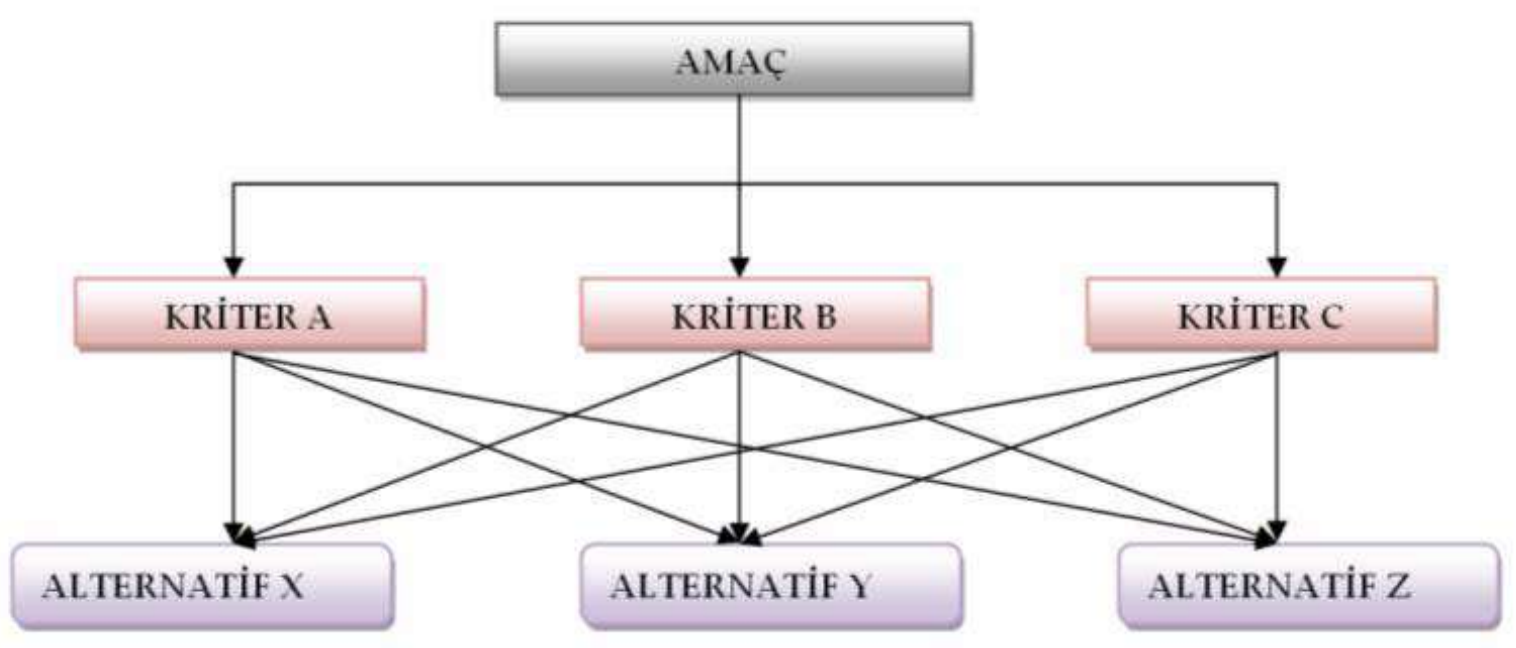

AHP'de hiyerarşik yapı tasarlandıktan sonra ikili karşılaştırma matrisleri oluşturulur. İkili karşılaştırma matrisleri, belirlenmiş bir ölçek doğrultusunda tüm kriterlerin birbiriyle karşılaştırılmasında kullanılır (Aktepe ve Ersöz, 2014: 4). Birçok kriter arasında değerlendirme yapmak için, genellikle nitel olarak yapılan yargılamalar sayısal olarak ifade edilir. Bunu yapmak için, dikkatli bir şekilde tasarlanmış ikili karşılaştırmalara ihtiyaç duyulur (Saaty, 2008: 124). Karşılaştırmanın yapılacağı hiyerarşide n sayıda kriterin bulunması durumunda $n .(n-1) / 2$ sayıda karş1laştırma yapılır (Byun, 2001: 290). Örneğin, 5 kriterli bir karar problemi 5.(5-1)/ $2=10$ adet ikili karşılaştırmayı gerektirmektedir. Kriterler için karşılaştırma matrisi Tablo 1.'de gösterilmiştir.

Tablo 1.Kriterler İçin İkili Karşılaştırma Matrisi Oluşturulması

\begin{tabular}{|l|l|l|l|l|}
\hline & Kriter 1 & Kriter 2 & Kriter... & Kriter j \\
\hline Kriter 1 & $W_{1} / W_{1}$ & $W_{1} / W_{\mathbf{2}}$ & $\ldots$ & $W_{1} / W_{j}$ \\
\hline Kriter 2 & $W_{\mathbf{2}} / W_{1}$ & $W_{\mathbf{2}} / W_{\mathbf{2}}$ & $\ldots$ & $W_{\mathbf{2}} / W_{j}$ \\
\hline Kriter... & $\ldots$ & $\ldots$ & $\ldots$ & $\ldots$ \\
\hline Kriter j & $W_{j} / W_{1}$ & $W_{j} / W_{\mathbf{2}}$ & $\ldots$ & $W_{j} / W_{j}$ \\
\hline
\end{tabular}

İkili karşılaş̧ırma matrisi oluşturulduktan sonra tüm kriterlerin birbirlerine karşı ne kadar önemli olduğunun belirlenmesi gerekir. Karşılaştırmalarda bu değerlendirmeyi yapabilmek için Saaty 1'den 9'a kadar değer verilen önem ölçeğini geliştirmiştir. Analitik hiyerarşi prosesinde genel olarak bu ölçekten yararlanılır (Arslan, 2010: 458). İkili karşılaştırma matrisinde wi/wj terimi, belirlenmiş olan amaca ulaşabilmek için $\mathrm{i}$ kriterinin, $\mathrm{j}$ kriterinden ne derece önemli olduğunu ifade eder. Örneğin, değer 7 ise, i kriterinin j kriterine göre çok kuvvetli derecede önemli olduğu anlaşılır. Dolayısıyla j kriteri de i kriterine göre 1/7 düzeyinde önemlidir (Uzun ve Kazan, 2016: 101). 
Tablo 2. Analitik Hiyerarşi Prosesinde Kullanılan Değerlendirme Ölçeği (Saaty, 1990: 15)

\begin{tabular}{|l|l|l|}
\hline $\begin{array}{l}\text { Önem } \\
\text { Derecesi }\end{array}$ & \multicolumn{1}{|c|}{ Tanım } & \multicolumn{1}{c|}{ Açıklama } \\
\hline 1 & Eşit Önemli & $\begin{array}{l}\text { İki seçenek amaca eşit seviyede katkıda } \\
\text { bulunur. }\end{array}$ \\
\hline 3 & Birinin diğerine göre çok az önemli olması & $\begin{array}{l}\text { Tecrübe ve yargı bir faaliyeti diğerine çok az } \\
\text { derecede tercih ettirir. }\end{array}$ \\
\hline 5 & Kuvvetli Derecede Önemli & $\begin{array}{l}\text { Tecrübe ve yargı bir faaliyeti diğerine kuvvetli } \\
\text { derecede tercih ettirir. }\end{array}$ \\
\hline 9 & Çok Kuvvetli Derecede Önemli & $\begin{array}{l}\text { Bir faaliyet güçlü bir şekilde tercih edilir ve } \\
\text { uygulamada baskınlık rahatlıkla görülür. }\end{array}$ \\
\hline $2,4,6,8$ & Ara (Ortalama) Değerler & $\begin{array}{l}\text { Bir faaliyetin diğerine tercih edilmesine ilişkin } \\
\text { kanıtlar çok büyük güvenilirliğe sahiptir. }\end{array}$ \\
\hline & Aşırı Derecede Önemli & $\begin{array}{l}\text { Uzlaşma gerektiğinde yukarıda listenen } \\
\text { yargılar arasına düşen değerler }\end{array}$ \\
\hline
\end{tabular}

İkili karşılaştırma matrisi oluşturulup kriterlere değer verildikten sonraki aşama, kriterlerin göreli önem derecelerinin belirlenmesidir. Göreli önem dereceleri üstünlük belirleme ya da ağırlık belirlemek için kullanılmaktadır.

Karşılaştırılan faktörlerin önceliğinin hesaplanmasında ilk olarak, matristeki her sütunun toplam değeri alınır ve her bir faktör bulunduğu sütunun toplam değerine bölünür. Böylece normalize edilmiş ikili karşılaştırma matrisi elde edilir. Daha sonra normalize edilen matriste, her satırdaki elemanların aritmetik ortalaması bulunur. Aritmetik ortalama öncelik vektörünü verir. İkili karşılaştırmalar matrisi ile öncelik vektörü çarpılır ve ağırlıklandırılmış toplam vektör bulunur (Kara, 2017: 584). Özvektörün formülü aşağıdaki gibidir (Ramadhan ve diğ., 1999: 29):

$$
W_{i}=\frac{1}{n} \sum_{j=1}^{n} \frac{a_{i j}}{\sum_{j=1}^{n} \text { aij }}
$$

$\mathrm{Bu}$ aşamaya kadar yapılan işlemlerin doğruluğunun kontrolü için tutarlılık oranının hesaplanması gerekir. Tutarlılık oranının hesaplanmadan önce tutarlılık göstergesi hesaplanır. Son olarak tutarlılık göstergesi rassallık göstergesine bölünür ve böylece tutarlılık oranı hesaplanmış olur. Rassallık göstergesi için Saaty’nin rassallık göstergesi tablosu kullanılır (Kara, 2017: 584). Tutarlılık göstergesi ve tutarlılık oranının formülü aşağıdaki gibidir (Dinçer ve Görener, 2011: 247):

$$
\begin{aligned}
& \text { Tutarlılık Göstergesi }=\frac{\lambda_{\max }-\mathrm{n}}{\mathrm{n}} \\
& \text { Tutarlılık Oranı }=\frac{\text { Tutarlılık Göstergesi }}{\text { Rassallık Gostergesi }}
\end{aligned}
$$

Tutarsızlık oranının $0.10^{\prime}$ dan küçük olması gerekir. Bu oranın 0.10 'u geçtiği durumlarda matris yeniden incelenmeli ve gerekli düzenlemelerin ardından adımlar tekrarlanmalıdır (Kapar, 2013: 211). Tutarsızlık oranın hesaplanması için kullanılan rassallık göstergeleri Tablo 3.'de verilmiştir.

Tablo 3. Rassallık Göstergeleri (Wang, Che ve Wu, 2010: 1024)

\begin{tabular}{|l|l|l|l|l|l|l|l|l|l|l|l|l|l|l|l|}
\hline $\mathbf{N}$ & $\mathbf{1}$ & $\mathbf{2}$ & $\mathbf{3}$ & $\mathbf{4}$ & $\mathbf{5}$ & $\mathbf{6}$ & $\mathbf{7}$ & $\mathbf{8}$ & $\mathbf{9}$ & $\mathbf{1 0}$ & $\mathbf{1 1}$ & $\mathbf{1 2}$ & $\mathbf{1 3}$ & $\mathbf{1 4}$ & $\mathbf{1 5}$ \\
\hline $\mathbf{R I}$ & 0 & 0 & 0,58 & 0,9 & 1,12 & 1,24 & 1,32 & 1,41 & 1,45 & 1,49 & 1,51 & 1,48 & 1,56 & 1,57 & 1,59 \\
\hline
\end{tabular}




\section{3.Önerilen Modelin Tasarlanması}

Bir model oluşturmanın en önemli adımı, problemi çözmek için modelin tasarlanması, yani modelin algoritmasının oluşturulmasıdır. Algoritma, herhangi bir problemin çözülmesinde veya herhangi bir amaca ulaşılmasında izlenecek olan yolu ifade eder. Model oluşturmada doğru bir yol izlemek algoritmanın oluşturulması ile gerçekleşir (Kömürcü, 2016: 28).

$\mathrm{Bu}$ çalışmada belirlenen amaç doğrultusunda önerilen modelin algoritması aşağıdaki şekilde oluşturulmuştur:

Araştırma kapsamındaki işletmenin pazarlama stratejilerinin belirlenmesi,

$>$ Literatür incelemesi ve konuyla ilgili bilimsel çalışmalara sahip olan akademisyenlerin görüşlerinin alınması ile ana ve alt ölçüt listesinin oluşturulması,

> Pazarlama stratejilerinin ikili karşılaştırmalarının yapılması, yerel ağırlıkların ve tutarsızlık oranının hesaplanmas1,

$>$ Her bir stratejiye göre ana kriterlerin ikili karşılaştırmalarının yapılması, yerel ağırlıkların ve tutarsızlık oranının hesaplanması,

> Her bir stratejiye göre alt kriterlerin ikili karşılaştırmalarının yapılması, yerel ağırlıkların ve tutarsızlık oranının hesaplanmas1,

> Modelde yer alan pazarlama performans ölçütlerinin genel ağırlıklarının hesaplanması,

$>$ Modelde yer alan pazarlama performans ölçütlerinin mevcut durumunun belirlenmesi,

$>$ Modelde yer alan pazarlama performans ölçütlerinin mevcut durum düzeyinin, genel ağırlıklar ve mevcut durum baz alınarak belirlenmesi,

$>$ Pazarlama performansının modelde yer alan ölçütler açısından genel değerlendirmesinin yapılması.

Modelin tasarlanmasında ilk aşama, araştırma kapsamındaki işletmenin pazarlama stratejilerinin belirlenmesidir. $\mathrm{Bu}$ nedenle işletmenin pazarlama yöneticisi ile görüşme sağlanmış ve vizyonları doğrultusunda belirledikleri pazarlama stratejileri öğrenilmiştir. Buna göre işletmenin belirlediği pazarlama stratejileri aşağıdaki gibidir:

1. Yeni ülke pazarlarında yer edinmek (PS1)

2. AR-GE desteği ile yeni ürünler geliştirmek (PS2)

3. Satış kanalını güçlendirmek (PS3)

Modelin daha sonraki aşaması ise stratejik pazarlama performansının belirlenmesinde kullanılan ölçütlerin sınıflandırılmasıdır. Sınıflandırmada kullanılan ölçütler incelenen literatür ve konuyla ilgili bilimsel çalışmalara sahip olan akademisyenlerin görüşleri alınarak şekillenmiştir. Ana kriterler; finansal, müşteri, süreç, ürün ve fiyat ölçütleri olmak üzere beş başlık altında değerlendirilmiştir ve her bir ana kriterin altında beşer tane olmak üzere toplam 25 alt kriter belirlenmiştir. Bu doğrultuda çalışmanın ana ve alt kriterleri aşağıdaki şekilde oluşturulmuştur:

Finansal Ölçütler (FNÖ)

Karl111k (FNÖ1)

Satışlar (FNÖ2)

Yatırımın Getirisi (FNÖ3)

Pazar Payı (FNÖ4)

Hissedar Değeri (FNÖ5)

Müşteri Ölçütleri (MŞÖ)

Müşteri Memnuniyeti (MŞÖ1)

Müşteri Sadakati (MŞÖ2)

Müşteri Yaşam Boyu Değeri (MŞÖ3)

Müşteri Güveni (MŞÖ4)

Yeni Müş̧teri Sayısı (MŞÖ5)

Süreç Ölçütleri (SRÖ)

Satış Süreci (Kişisel Satış, İyileştirme) (SRÖ1)

Satış Öncesi Süreç (Sipariş, Ürün/Hizmetlerin İyileştirilmesi, Dağıtım) (SRÖ2)

Satış Sonrası Süreç (Müşteri Hizmetleri, Geri Bildirim, Dağıtım,) (SRÖ3)

Yenilik Süreci (SRÖ4)

Müşteri Etkileşim Süreci (SRÖ5)

Ürün Ölçütleri (ÜRÖ)

Yeni Ürün Sayısı (ÜRÖ1)

Ürün Bulunabilirliği (ÜRÖ2) 
Yeni Ürün Konseptine Olan İnanç (ÜRÖ3)

Ürün Çeşitliliği (ÜRÖ4)

Ürün Kalitesi (Performans ve Tutarl11ık Kalitesi) (ÜRÖ5)

Fiyat Ölçütleri (FYÖ)

Fiyat Esnekliği (FYÖ1)

Fiyatlandırma Becerisi (FYÖ2)

Fiyat Primi (FYÖ3)

Göreceli Fiyat (FYÖ4)

Fiyatlandırma Tekniği (FYÖ5)

Yukarıda verilen pazarlama stratejileri ve pazarlama performansının ölçülmesinde kullanılan ana ve alt ölçüt listesine göre oluşturulan model Şekil 2.'de verilmiştir. Modelin birinci seviyesinde amaç, ikinci seviyesinde pazarlama stratejileri, üçüncü seviyesinde ana ölçütler, dördüncü seviyesinde ise alt ölçütler yer almaktadır.

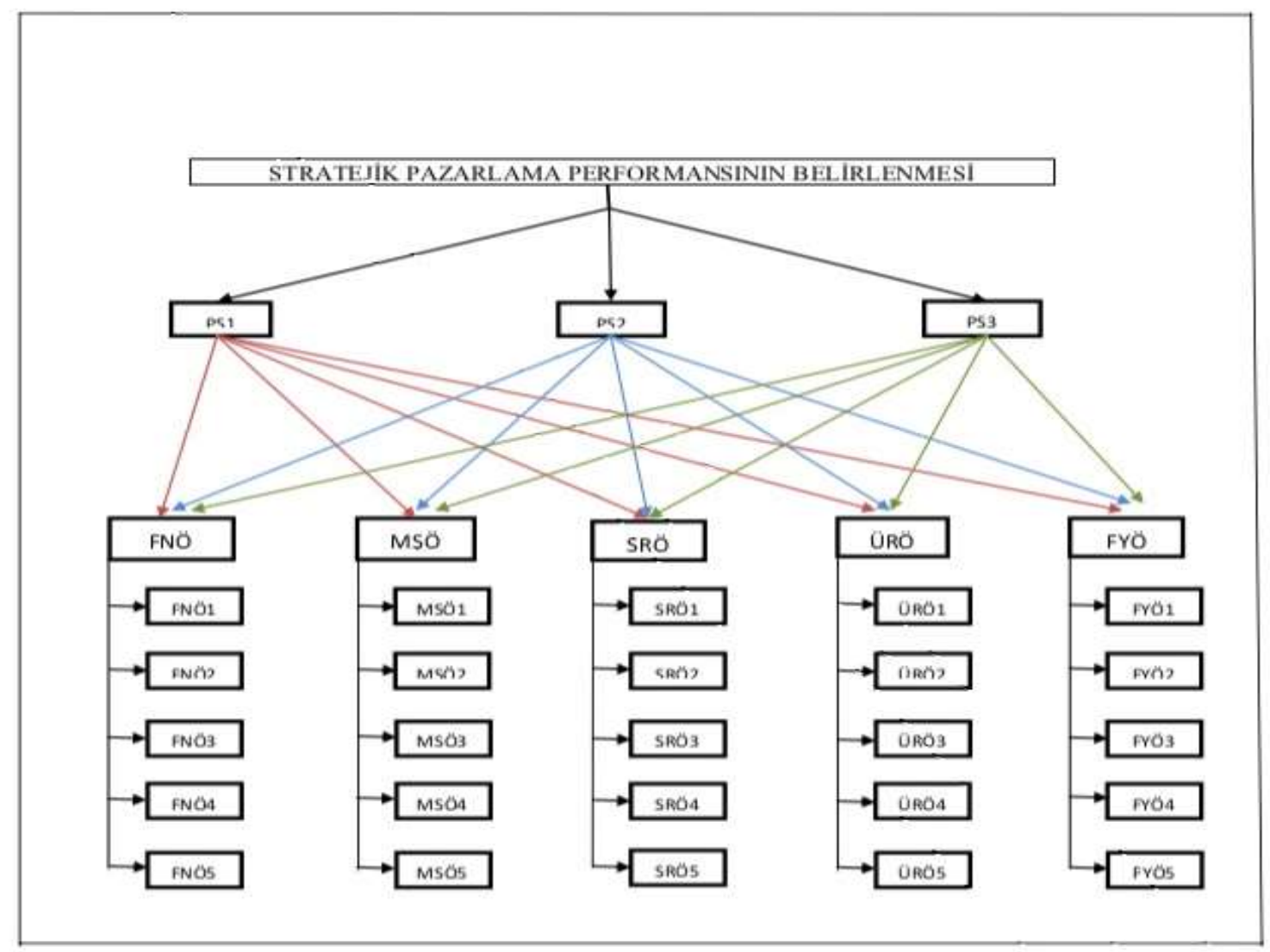

Sekil 2. AHP Modeli

\subsection{1.İkili Karşılaştırmaların Yapılması}

Çalışmada kullanılacak pazarlama stratejileri ve ölçütler belirlendikten sonra sıra ikili karşılaştırmaların yapılmasına gelmiştir. İkili karşılaştırmalar için Tablo 2'de verilen Saaty'nin değerlendirme ölçeğinden yararlanılmıştır. Matrislerin yerel ağırlıkları ve tutarsızlık oranları Exper Choice programı ile belirlenmiştir. Çalışmada ilk olarak işletmenin pazarlama performansını belirlerken baz aldığı pazarlama stratejilerinin ikili karşılaştırması yapılmıştır. Hesaplanan yerel ağırlıklara göre işletmenin en fazla ağırlığa sahip olan pazarlama stratejisinin, "satış kanalını güçlendirmek" olduğu belirlenmiştir. Bu stratejiyi sırasıyla "AR-GE desteğiyle yeni ürünler geliştirmek" stratejisi ve "yeni ülke pazarlarında yer edinmek" stratejisi izlemiştir. Matrisin tutarsızlık oranı 0.04 olarak hesaplanmıştır. Bu oran AHP'nin önerdiği sınırlar içerisinde olduğu için ikili karşılaştırmaların tutarlı olduğu kabul edilmiştir. 
Tablo 4. Pazarlama Stratejilerinin İkili Karşılaştırması

\begin{tabular}{|l|l|l|l|l|}
\hline Pazarlama Stratejileri & PS1 & PS2 & PS3 & $\begin{array}{l}\text { Yerel } \\
\text { Ağırlıklar }\end{array}$ \\
\hline Yeni ülke pazarlarında yer edinmek (PS1) & 1 & $1 / 3$ & $1 / 5$ & 0.105 \\
\hline AR-GE desteği ile yeni ürünler geliştirmek (PS2) & & 1 & $1 / 3$ & 0.258 \\
\hline
\end{tabular}

Pazarlama stratejilerinin yerel ağırlıkları hesaplandıktan sonra her bir stratejiye göre ana ölçütlerin ikili karşılaştırılması yapılmıştır. Tablo 5'de "Yeni ülke pazarlarında yer edinmek" stratejisine göre ana ölçütlerin ikili karşılaştırmaları ve yerel ağırlıkları verilmiştir. Bu stratejiye göre stratejik pazarlama performansının belirlenmesinde öncelikli ana ölçüt grubu ürün ölçütleridir. Ürün ölçütlerini sırasıyla süreç ölçütleri, müşteri ölçütleri, fiyat ölçütleri ve finansal ölçütler izlemiştir. Matrise ilişkin tutarsızlık oranı 0.06 olarak hesaplanmıştır. Bu oran AHP'nin önerdiği sınırlar içerisinde olduğu için ikili karşılaştırmaların tutarlı olduğu kabul edilmiştir.

Tablo 5. "Yeni Ülke Pazarlarında Yer Edinmek" Stratejisine Göre Ana Kriterlerin İkili Karşılaştırması

\begin{tabular}{|l|l|l|l|l|l|l|}
\hline Ana Kriterler & FNÖ & MŞÖ & SRÖ & ÜRÖ & FYÖ & $\begin{array}{l}\text { Yerel } \\
\text { Ăğırlıklar }\end{array}$ \\
\hline Finansal Ölçütler (FNÖ) & 1 & $1 / 2$ & $1 / 3$ & $1 / 5$ & $1 / 3$ & 0.064 \\
\hline Müşteri Ölçütleri (MŞÖ) & & 1 & $1 / 2$ & $1 / 4$ & 3 & 0.157 \\
\hline Süreç Ölçütleri (SRÖ) & & & 1 & $1 / 3$ & 2 & 0.205 \\
\hline Ürün Ölçütleri (ÜRÖ) & & & & 1 & 4 & 0.466 \\
\hline Fiyat Ölçütleri (FYÖ) & & & & & 1 & 0.108 \\
\hline
\end{tabular}

Tablo 6'da “AR-GE desteği ile yeni ürünler geliştirmek” stratejisine göre ana ölçütlerin ikili karşılaştırmaları ve yerel ağırlıkları verilmiştir. Bu stratejiye göre stratejik pazarlama performansının belirlenmesinde ürün ölçütlerinin öncelikli olduğu görülmüştür. İkinci sırada finansal ölçütler, üçüncü sırada müşteri ölçütleri, dördüncü sırada ise aynı ağırlığa sahip olan süreç ve fiyat ölçütleri yer almıştır. Matrise ilişkin tutarsızlık oranı ise 0.06 olarak hesaplanmıştır. Bu oran AHP'nin önerdiği sınırlar içerisinde olduğundan ikili karşılaştırmaların tutarlı olduğu kabul edilmiştir.

Tablo 6. “AR-GE Desteği İle Yeni Ürünler Geliştirmek” Stratejisine Göre Ana Kriterlerin İkili Karşılaştırması

\begin{tabular}{|l|l|l|l|l|l|l|}
\hline Ana Kriterler & FNÖ & MŞÖ & SRÖ & ÜRÖ & FYÖ & $\begin{array}{l}\text { Yerel } \\
\text { Ăğırlıklar }\end{array}$ \\
\hline Finansal Ölçütler (FNÖ) & 1 & 2 & 3 & $1 / 3$ & 3 & 0.237 \\
\hline Müşteri Ölçütleri (MŞÖ) & & 1 & 3 & $1 / 3$ & 3 & 0.180 \\
\hline Süreç Ölçütleri (SRÖ) & & & 1 & $1 / 3$ & 1 & 0.085 \\
\hline Ürün Ölçütleri (ÜRÖ) & & & & 1 & 3 & 0.413 \\
\hline Fiyat Ölçütleri (FYÖ) & & & & & 1 & 0.085 \\
\hline
\end{tabular}

Tutarsızlık Oranı: 0.06 
Tablo 7'de "Satış kanalını güçlendirmek" stratejisine göre ana ölçütlerin ikili karşılaştırması ve yerel ağırlıklar verilmiştir. Bu stratejiye göre en fazla ağırlığa sahip olan ölçüt grubu ürün ölçütleridir. Ürün ölçütlerini sırasıyla, süreç ölçütleri, müşteri ölçütleri, fiyat ölçütleri ve finansal ölçütler izlemiştir. Matrisin tutarsızlık oranı 0.08 olarak hesaplanmıştır. Bu oran ikili karşılaştırmaların tutarlı olduğunu göstermektedir.

Tablo 7. "Satış Kanalını Güçlendirmek” Stratejisine Göre Ana Kriterlerin İkili Karşılaştırması

\begin{tabular}{|l|l|l|l|l|l|l|}
\hline Ana Kriterler & FNÖ & MŞÖ & SRÖ & ÜRÖ & FYÖ & $\begin{array}{l}\text { Yerel } \\
\text { Ăğırlıklar }\end{array}$ \\
\hline Finansal Ölçütler (FNÖ) & 1 & $1 / 3$ & $1 / 3$ & $1 / 5$ & $1 / 3$ & 0.059 \\
\hline Müşteri Ölçütleri (MŞÖ) & & 1 & $1 / 2$ & $1 / 3$ & 4 & 0.192 \\
\hline Süreç Ölçütleri (SRÖ) & & & 1 & $1 / 3$ & 2 & 0.209 \\
\hline Ürün Ölçütleri (ÜRÖ) & & & & 1 & 4 & 0.439 \\
\hline Fiyat Ölçütleri (FYÖ) & & & & & 1 & 0.101 \\
\hline
\end{tabular}

Tablo 8'de "Yeni ülke pazarlarında yer edinmek" stratejisine göre finansal ölçütlerin ikili karşılaştırmaları ve yerel ağırlıkları verilmiştir. Buna göre finansal ölçütler arasında en fazla ağırlığa sahip olan ölçüt pazar payıdır. Pazar payını sırasıyla satışlar, karlılık, yatırımın getirisi ve hissedar değeri takip etmiştir. Matrise ilişkin tutarsızlık oranı 0.03 olarak hesaplanmıştır. $\mathrm{Bu}$ oran ikili karşılaştırmaların tutarlı olduğunu göstermektedir.

\section{Tablo 8. "Yeni Ülke Pazarlarında Yer Edinmek Stratejisine Göre Finansal Ölçütlerin İkili Karşılaştırması}

\begin{tabular}{|l|l|l|l|l|l|l|}
\hline Finansal Ölçütler & FNÖ1 & FNÖ2 & FNÖ3 & FNÖ4 & FNÖ5 & $\begin{array}{l}\text { Yerel } \\
\text { Ağırlıklar }\end{array}$ \\
\hline Karlı1ık (FNÖ1) & 1 & $1 / 2$ & 2 & $1 / 3$ & 3 & 0.155 \\
\hline Satışlar (FNÖ2) & & 1 & 4 & 1 & 5 & 0.323 \\
\hline Yatırımın Getirisi (FNÖ3) & & & 1 & $1 / 5$ & 3 & 0.096 \\
\hline Pazar Payı (FNÖ4) & & & & 1 & 5 & 0.372 \\
\hline Hissedar Değeri (FNÖ5) & & & & & 1 & 0.054 \\
\hline Tutarsızık Oranı: 0.03
\end{tabular}

Tablo 9'da "Yeni ülke pazarlarında yer edinmek” stratejisine göre müşteri ölçütlerinin ikili karşılaştırmaları ve yerel ağırlıkları verilmiştir. Buna göre müşteri ölçütleri arasında en fazla ağırlığa sahip olan ölçüt müşteri memnuniyetidir. Bu ölçütü sırasıyla müşteri güveni, yeni müşteri sayısı, müşteri sadakati ve müşteri yaşam boyu değeri takip etmiştir. Matrise ilişkin tutarsızlık oranı 0.09 olarak hesaplanmıştır. $\mathrm{Bu}$ oran ikili karşılaştırmaların tutarlı olduğunu göstermektedir. 
Tablo 9. “Yeni Ülke Pazarlarında Yer Edinmek” Stratejisine Göre Müşteri Ölçütlerinin İkili Karşılaştırması

\begin{tabular}{|l|c|c|c|c|c|l|}
\hline Müşteri Ölçütleri & MŞÖ1 & MŞÖ2 & MŞÖ3 & MŞÖ4 & MŞÖ5 & $\begin{array}{l}\text { Yerel } \\
\text { Ağırlıklar }\end{array}$ \\
\hline Müşteri Memnuniyeti (MŞÖ1) & 1 & 2 & 3 & 2 & 4 & 0.372 \\
\hline Müşteri Sadakati (MŞÖ2) & & 1 & 2 & $1 / 3$ & $1 / 3$ & 0.106 \\
\hline Müşteri Yaşam Boyu Değeri (MŞÖ3) & & & 1 & $1 / 5$ & $1 / 3$ & 0.066 \\
\hline Müşteri Güveni (MŞÖ4) & & & & 1 & 3 & 0.297 \\
\hline Yeni Müşteri Sayısı (MŞÖ5) & & & & & 1 & 0.160 \\
\hline Tutarsılık Oranı: 0.09
\end{tabular}

Tablo 10'da "Yeni ülke pazarlarında yer edinmek" stratejisine göre süreç ölçütlerinin ikili karşılaştırmaları ve yerel ağırlıkları verilmiştir. Buna göre süreç ölçütleri içerisinde en fazla ağırlığa sahip olan ölçüt satış öncesi süreçtir. Bu ölçütü sırasıyla, satış süreci, satış sonrası süreç, müşteri etkileşim süreci ve yenilik süreci takip etmiştir. Matrise ilişkin tutarsızlık oranı 0.08 olarak hesaplanmıştır. Bu oran ikili karşılaştırmaların tutarlı olduğunu göstermektedir.

Tablo 10. "Yeni Ülke Pazarlarında Yer Edinmek” Stratejisine Göre Süreç Ölçütlerinin İkili Karşılaştırması

\begin{tabular}{|l|l|l|l|l|l|l|}
\hline Süreç Ölçütleri & SRÖ1 & SRÖ2 & SRÖ3 & SRÖ4 & SRÖ5 & $\begin{array}{l}\text { Yerel } \\
\text { Ă̆ırlıklar }\end{array}$ \\
\hline Satış Süreci (SRÖ1) & 1 & $1 / 4$ & 3 & 5 & 3 & 0.255 \\
\hline Satı̧̧ Öncesi Süreç (SRÖ2) & & 1 & 3 & 4 & 3 & 0.450 \\
\hline Satış Sonrası Süreç (SRÖ3) & & & 1 & 3 & 2 & 0.139 \\
\hline Yenilik Süreci (SRÖ4) & & & & 1 & $1 / 2$ & 0.059 \\
\hline Müşteri Etkileşim Süreci (SRÖ5) & & & & & 1 & 0.097 \\
\hline
\end{tabular}

Tablo 11'de "Yeni ülke pazarlarında yer edinmek" stratejisine göre ürün ölçütlerinin ikili karşılaştırması ve yerel ağırlıkları verilmiştir. Buna göre ürün ölçütleri arasında en fazla ağırlığa sahip olan ölçüt, ürün kalitesidir. İkinci sırada ürün bulunabilirliği, üçüncü sırada yeni ürün konseptine olan inanç yer almıştır. Ürün çeşitliliği ve yeni ürün sayısı ölçütleri ise aynı ağırlığa sahip olarak dördüncü ve son sırayı paylaşmışlardır. Matrise ilişkin tutarsızlık oranı 0.08 olarak hesaplanmıştır. Bu değer ikili karşılaştırmaların tutarlı olduğunu göstermektedir.

Tablo 11. "Yeni Ülke Pazarlarında Yer Edinmek” Stratejisine Göre Ürün Ölçütlerinin İkili Karşılaştırması

\begin{tabular}{|l|l|l|l|l|l|l|}
\hline Ürün Ölçütleri & ÜRÖ1 & ÜRÖ2 & ÜRÖ3 & ÜRÖ4 & ÜRÖ5 & $\begin{array}{l}\text { Yerel } \\
\text { Ağırlıklar }\end{array}$ \\
\hline Yeni Ürün Sayısı (ÜRÖ1) & 1 & $1 / 4$ & $1 / 3$ & 1 & $1 / 5$ & 0.061 \\
\hline Ürün Bulunabilirliği (ÜRÖ2) & & 1 & 3 & 4 & $1 / 5$ & 0.226 \\
\hline Yeni Ürün Konseptine Olan İnanç (ÜRÖ3) & & & 1 & 3 & $1 / 4$ & 0.131 \\
\hline
\end{tabular}




\begin{tabular}{|l|l|l|l|l|l|l|}
\hline Ürün Çeşitliliği (ÜRÖ4) & & & & 1 & $1 / 5$ & 0.061 \\
\hline Ürün Kalitesi (ÜRÖ5) & & & & & 1 & 0.521 \\
\hline
\end{tabular}

Tablo 12'de "Yeni ülke pazarlarında yer edinmek" stratejisine göre fiyat ölçütlerinin ikili karşılaştırması ve yerel ağırlıklar verilmiştir. Buna göre fiyat ölçütleri arasında en fazla ağırlığa sahip olan ölçüt, fiyatlandırma tekniğidir. Bu ölçütü sırasıyla fiyatlandırma becerisi, fiyat primi, göreceli fiyat ve fiyat esnekliği ölçütleri takip etmiştir. Matrise ilişkin tutarsızlık oranı 0.07 olarak hesaplanmıştır. Bu oran ikili karşılaştırmaların tutarlı olduğunu göstermektedir.

Tablo 12. "Yeni Ülke Pazarlarında Yer Edinmek" Stratejisine Göre Fiyat Ölçütlerinin İkili Karşılaştırması

\begin{tabular}{|l|l|l|l|l|l|l|}
\hline Fiyat Ölçütleri & FYÖ1 & FYÖ2 & FYÖ3 & FYÖ4 & FYÖ5 & $\begin{array}{l}\text { Yerel } \\
\text { Ağırlıklar }\end{array}$ \\
\hline Fiyat Esnekliği (FYÖ1) & 1 & $1 / 5$ & $1 / 3$ & $1 / 3$ & $1 / 5$ & 0.051 \\
\hline Fiyatlandırma Becerisi (FYÖ2) & & 1 & 4 & 3 & $1 / 2$ & 0.297 \\
\hline Fiyat Primi (FYÖ3) & & & 1 & 3 & $1 / 4$ & 0.138 \\
\hline Göreceli Fiyat (FYÖ4) & & & & 1 & $1 / 5$ & 0.088 \\
\hline Fiyatlandırma Tekniği (FYÖ5) & & & & & 1 & 0.426 \\
\hline
\end{tabular}

Tablo 13'de "AR-GE desteği ile yeni ürünler geliştirmek" stratejisine göre finansal ölçütlerin ikili karşılaş̧ırmalarına ilişkin matris değerleri ve yerel ağırlıklar verilmiştir. Buna göre finansal ölçütler arasında öncelikli ölçütün satışlar olduğu görülmüştür. Bu ölçütü sırasıyla pazar payı, karlılık, yatırım getirisi ve hissedar değeri takip etmiştir. Matrise ilişkin tutarsızlık oranı 0.08 bulunmuştur. Bu değer ikili karşılaştırmaların tutarlı olduğunu göstermektedir.

Tablo 13. “AR-GE Desteği İle Yeni Ürünler Geliştirmek” Stratejisine Göre Finansal Ölçütlerin İkili Karşılaştırması

\begin{tabular}{|l|l|l|l|l|l|l|}
\hline Finansal Ölçütler & FNÖ1 & FNÖ2 & FNÖ3 & FNÖ4 & FNÖ5 & $\begin{array}{l}\text { Yerel } \\
\text { Ağırlıklar }\end{array}$ \\
\hline Karlı1ık (FNÖ1) & 1 & $1 / 3$ & 3 & 1 & 3 & 0.198 \\
\hline Satışlar (FNÖ2) & & 1 & 5 & 1 & 5 & 0.379 \\
\hline Yatırımın Getirisi (FNÖ3) & & & 1 & $1 / 3$ & 5 & 0.109 \\
\hline Pazar Payı (FNÖ4) & & & & 1 & 5 & 0.264 \\
\hline Hissedar Değeri (FNÖ5) & & & & & 1 & 0.050 \\
\hline
\end{tabular}

Tablo 14'de “AR-GE desteği ile yeni ürünler geliştirmek” stratejisine göre müşteri ölçütlerinin ikili karşılaştırmalarına ilişkin matris değerleri ve yerel ağırlıklar verilmiştir. Buna göre müşteri ölçütlerinde öncelikli ölçütün müş̧eri memnuniyeti olduğu görülmüştür. Müşteri memnuniyetini sırasılyla, müşteri güveni, müşteri sadakati, müşteri yaşam boyu değeri ve yeni müşteri sayısı takip etmiş̧ir. Matrise ilişkin tutarsılzlk oranı 0.07 olarak hesaplanmıştır. Bu değer ikili karşılaştırmaların tutarlı olduğunu göstermektedir. 
Tablo 14. “AR-GE Desteği İle Yeni Ürünler Geliştirmek” Stratejisine Göre Müşteri Ölçütlerinin İkili Karşılaştırması

\begin{tabular}{|l|l|l|l|l|l|l|}
\hline Müşteri Ölçütleri & MŞÖ1 & MŞÖ2 & MŞÖ3 & MŞÖ4 & MŞÖ5 & $\begin{array}{l}\text { Yerel } \\
\text { Ağırlıklar }\end{array}$ \\
\hline Müşteri Memnuniyeti (MŞÖ1) & 1 & 5 & 5 & 2 & 5 & 0.450 \\
\hline Müşteri Sadakati (MŞÖ2) & & 1 & 3 & $1 / 2$ & 3 & 0.145 \\
\hline Müşteri Yaşam Boyu Değeri (MŞÖ3) & & & 1 & $1 / 5$ & 3 & 0.081 \\
\hline Müşteri Güveni (MŞÖ4) & & & & 1 & 5 & 0.273 \\
\hline Yeni Müşteri Sayı11 (MŞÖ5) & & & & & 1 & 0.051 \\
\hline
\end{tabular}

Tablo 15'de "AR-GE desteği ile yeni ürünler geliştirmek" stratejisine göre süreç ölçütlerine ilişkin ikili karşılaştırmalar ve yerel ağırlıklar verilmiştir. Buna göre süreç ölçütleri içerisinde en fazla ağırlığa satış öncesi süreç sahiptir. Satış öncesi süreci sırasıyla, satış süreci, satış sonrası süreç, müşteri etkileşim süreci ve yenilik süreci takip etmiştir. Matrise ilişkin tutarsızlık oranı 0.08 olarak hesaplanmıştır. Bu değer ikili karşılaştırmaların tutarlı olduğunu göstermektedir.

Tablo 15. “AR-GE Desteği İle Yeni Ürünler Geliştirmek” Stratejisine Göre Süreç Ölçütlerinin İkili Karşılaştırması

\begin{tabular}{|l|l|l|l|l|l|l|}
\hline Süreç Ölçütleri & (SRÖ1) & (SRÖ2) & (SRÖ3) & (SRÖ4) & (SRÖ5) & $\begin{array}{l}\text { Yerel } \\
\text { Ağırlıklar }\end{array}$ \\
\hline Satış Süreci (SRÖ1) & 1 & $1 / 3$ & 2 & 3 & 2 & 0.225 \\
\hline Satış Öncesi Süreç (SRÖ2) & & 1 & 3 & 2 & 3 & 0.396 \\
\hline Satış Sonrası Süreç (SRÖ3) & & & 1 & 3 & 2 & 0.172 \\
\hline Yenilik Süreci (SRÖ4) & & & & 1 & $1 / 2$ & 0.089 \\
\hline Müşteri Etkileşim Süreci (SRÖ5) & & & & & 1 & 0.117 \\
\hline
\end{tabular}

Tablo 16'da "AR-GE desteği ile yeni ürünler geliştirmek” stratejisine göre ürün ölçütlerine ilişkin ikili karşılaştırmalar ve yerel ağırlıklar verilmiştir. Buna göre ürün ölçütlerinde öncelikli ölçütün ürün kalitesi olduğu saptanmıştır. Bu ölçütler arasında ürün bulunabilirliği ikinci sırayı alırken, yeni ürün konseptine olan inanç üçüncü sırada yer almıştır. Ürün çeşitliliği ve yeni ürün sayısı ölçütleri ise eşit ve en az ağırlı̆ga sahip olarak son sırada yer almışlardır. Matrise ilişkin tutarsızlık oranı 0.04 olarak hesaplanmıştır. Bu değer ikili karşılaştırmaların tutarlı olduğunu göstermektedir.

Tablo 16. “AR-GE Desteği İle Yeni Ürünler Geliştirmek” Stratejisine Göre Ürün Ölçütlerinin İkili Karşılaştırması

\begin{tabular}{|l|l|l|l|l|l|l|}
\hline Ürün Ölçütleri & ÜRÖ1 & ÜRÖ2 & ÜRÖ3 & ÜRÖ4 & ÜRÖ5 & $\begin{array}{l}\text { Yerel } \\
\text { Ağırlıklar }\end{array}$ \\
\hline Yeni Ürün Say1s1 (ÜRÖ1) & 1 & $1 / 3$ & $1 / 3$ & 1 & $1 / 5$ & 0.069 \\
\hline Ürün Bulunabilirliği (ÜRÖ2) & & 1 & 2 & 3 & $1 / 4$ & 0.203 \\
\hline Yeni Ürün Konseptine Olan İnanç (ÜRÖ3) & & & 1 & 3 & $1 / 4$ & 0.154 \\
\hline
\end{tabular}




\begin{tabular}{|l|l|l|l|l|l|l|}
\hline Ürün Çeşitliliği (ÜRÖ4) & & & & 1 & $1 / 5$ & 0.069 \\
\hline Ürün Kalitesi (ÜRÖ5) & & & & & 1 & 0.506 \\
\hline
\end{tabular}

Tablo 17'de "AR-GE desteği ile yeni ürünler geliştirmek” stratejisine göre fiyat ölçütlerine ilişkin ikili karşılaştırmalar ve yerel ağırlıklar yer almaktadır. Buna göre fiyat ölçütleri arasında en fazla ağırlığa fiyatlandırma tekniği sahiptir. Fiyatlandırma tekniğini sırasıyla, fiyatlandırma becerisi, fiyat primi, göreceli fiyat ve fiyat esnekliği izlemiştir. Matrise ilişkin tutarsızlık oranı 0.07 olarak hesaplanmıştır. Bu değer ikili karşılaştırmaların tutarlı olduğunu göstermektedir.

Tablo 17. “AR-GE Desteği İle Yeni Ürünler Geliştirmek” Stratejisine Göre Fiyat Ölçütlerinin İkili Karşılaştırması

\begin{tabular}{|l|l|l|l|l|l|l|}
\hline Fiyat Ölçütleri & FYÖ1 & FYÖ2 & FYÖ3 & FYÖ4 & FYÖ5 & $\begin{array}{l}\text { Yerel } \\
\text { Ăğırlıklar }\end{array}$ \\
\hline Fiyat Esnekliği (FYÖ1) & 1 & $1 / 2$ & $1 / 2$ & $1 / 3$ & $1 / 3$ & 0.088 \\
\hline Fiyatlandırma Becerisi (FYÖ2) & & 1 & 3 & 2 & 1 & 0.289 \\
\hline Fiyat Primi (FYÖ3) & & & 1 & 2 & $1 / 3$ & 0.153 \\
\hline Göreceli Fiyat (FYÖ4) & & & & 1 & $1 / 3$ & 0.138 \\
\hline Fiyatlandırma Tekniği (FYÖ5) & & & & & 1 & 0.332 \\
\hline
\end{tabular}

Tablo 18'de "Satış kanalını güçlendirmek" stratejisine göre finansal ölçütlerin ikili karşılaştırması ve yerel ağırlıklar verilmiştir. Buna göre finansal ölçütler arasında en fazla ağırlığa sahip olan ölçüt satışlardır. Bu ölçütü sırasıyla pazar payı, karlılık, yatırımın getirisi ve hissedar değeri takip etmiştir. Matrisin tutarsızlık oranı 0.06 olarak hesaplanmıştır. Bu oran ikili karş1laştırmaların tutarlı olduğunu göstermektedir.

Tablo 18. "Satış Kanalını Güçlendirmek Stratejisine" Göre Finansal Ölçütlerin İkili Karşılaştırması

\begin{tabular}{|l|l|l|l|l|l|l|}
\hline Finansal Ölçütler & FNÖ1 & FNÖ2 & FNÖ3 & FNÖ4 & FNÖ5 & $\begin{array}{l}\text { Yerel } \\
\text { Ağırlıklar }\end{array}$ \\
\hline Karlı1ık (FNÖ1) & 1 & $1 / 4$ & 3 & $1 / 2$ & 5 & 0.173 \\
\hline Satışlar (FNÖ2) & & 1 & 4 & 2 & 5 & 0.425 \\
\hline Yatırımın Getirisi (FNÖ3) & & & 1 & $1 / 4$ & 3 & 0.087 \\
\hline Pazar Payı (FNÖ4) & & & & 1 & 5 & 0.268 \\
\hline Hissedar Değeri (FNÖ5) & & & & & 1 & 0.047 \\
\hline Tutarsızlı Oranı: 0.06
\end{tabular}

Tablo 19' da “Satış kanalını güçlendirmek” stratejisine göre müşteri ölçütlerinin ikili karşılaştırması ve yerel ağırlıklar verilmiştir. Buna göre müşteri ölçütleri arasında en fazla ağırlığa sahip olan ölçüt müşteri memnuniyetidir. Bu ölçütü sırasıyla, müşteri güveni, müşteri sadakati, müşteri yaşam boyu değeri ve yeni müşteri sayısı takip etmiştir. Matrisin tutarsızlık oranı 0.09 olarak hesaplanmıştır. Bu oran ikili karşılaştırmaların tutarlı olduğunu göstermektedir. 
Tablo 19. "Satış Kanalını Güçlendirmek” Stratejisine Göre Müşteri Ölçütlerinin İkili Karşılaştırması

\begin{tabular}{|l|l|l|l|l|l|l|}
\hline Müşteri Ölçütleri & MŞö1 & MŞö2 & MŞö3 & MŞÖ4 & MŞö5 & $\begin{array}{l}\text { Yerel } \\
\text { Ağırlıklar }\end{array}$ \\
\hline Müşteri Memnuniyeti (MŞÖ1) & 1 & 4 & 5 & 2 & 4 & 0.432 \\
\hline Müşteri Sadakati (MŞÖ2) & & 1 & 3 & $1 / 2$ & 3 & 0.165 \\
\hline Müşteri Yaşam Boyu Değeri (MŞÖ3) & & & 1 & $1 / 3$ & 4 & 0.105 \\
\hline Müşteri Güveni (MŞÖ4) & & & & 1 & 3 & 0.237 \\
\hline Yeni Müşteri Sayısı (MŞÖ5) & & & & & 1 & 0.061 \\
\hline Tutarsılık Oranı: 0.09 & & & & & &
\end{tabular}

Tablo 20'de "Satış kanalını güçlendirmek" stratejisine göre süreç ölçütlerinin ikili karşılaştırması ve yerel ağırlıklar verilmiştir. Buna göre süreç ölçütleri arasında en fazla ağırlığa sahip olan ölçüt, satış sürecidir. Bu ölçütü sırasıyla, satış öncesi süreç, satış sonrası süreç, müşteri etkileşim süreci ve yenilik süreci takip etmiştir. Matrisin tutarsızlık oranı 0.06 olarak hesaplanmıştır. $\mathrm{Bu}$ oran ikili karşılaştırmaların tutarlı olduğunu göstermektedir.

Tablo 20. "Satış Kanalını Güçlendirmek” Stratejisine Göre Süreç Ölçütlerinin İkili Karşılaştırması

\begin{tabular}{|l|l|l|l|l|l|l|}
\hline Süreç Ölçütleri & (SRÖ1) & (SRÖ2) & (SRÖ3) & (SRÖ4) & (SRÖ5) & $\begin{array}{l}\text { Yerel } \\
\text { Ă̆ırlıklar }\end{array}$ \\
\hline Satı̧̧ Süreci (SRÖ1) & 1 & 2 & 3 & 3 & 4 & 0.382 \\
\hline Satı̧̧ Öncesi Süreç (SRÖ2) & & 1 & 3 & 4 & 4 & 0.302 \\
\hline Satış Sonrası Süreç (SRÖ3) & & & 1 & 3 & 3 & 0.161 \\
\hline Yenilik Süreci (SRÖ4) & & & & 1 & $1 / 2$ & 0.070 \\
\hline Müşteri Etkileşim Süreci (SRÖ5) & & & & & 1 & 0.085 \\
\hline
\end{tabular}

Tablo 21'de "Satış kanalını güçlendirmek" stratejisine göre ürün ölçütlerinin ikili karşılaştırması ve yerel ağırlıklar verilmiştir. Buna göre ürün ölçütleri arasında en fazla ağırlığa sahip olan ölçüt, ürün kalitesidir. Bu ölçütü sırasıyla, ürün bulunabilirliği, yeni ürün konseptine olan inanç, ürün çeşitliliği ve yeni ürün sayısı takip etmiştir. Matrise ilişkin tutarsızlık oranı 0.08 olarak hesaplanmıştır. $\mathrm{Bu}$ oran ikili karşılaştırmaların tutarlı olduğunu göstermektedir.

Tablo 21. "Satış Kanalını Güçlendirmek" Stratejisine Göre Ürün Ölçütlerinin İkili Karşılaştırması

\begin{tabular}{|l|l|l|l|l|l|l|}
\hline Ürün Ölçütleri & ÜRÖ1 & ÜRÖ2 & ÜRÖ3 & ÜRÖ4 & ÜRÖ5 & $\begin{array}{l}\text { Yerel } \\
\text { Ağırlıklar }\end{array}$ \\
\hline Yeni Ürün Sayısı (ÜRÖ1) & 1 & $1 / 3$ & $1 / 4$ & $1 / 2$ & $1 / 5$ & 0.056 \\
\hline Ürün Bulunabilirliği (ÜRÖ2) & & 1 & 2 & 3 & $1 / 5$ & 0.184 \\
\hline Yeni Ürün Konseptine Olan İnanç (ÜRÖ3) & & & 1 & 3 & $1 / 5$ & 0.149 \\
\hline Ürün Çeşitliliği (ÜRÖ4) & & & & 1 & $1 / 5$ & 0.076 \\
\hline Ürün Kalitesi (ÜRÖ5) & & & & & 1 & 0.535 \\
\hline
\end{tabular}


Tablo 22'de "Satış kanalını güçlendirmek" stratejisine göre fiyat ölçütlerinin ikili karşılaştırması ve yerel ağırlıklar verilmiştir. Buna göre fiyat ölçütleri arasında en fazla ağırlı̆̆a sahip olan ölçüt, fiyatlandırma tekniğidir. Bu ölçütü sırasıyla, fiyatlandırma becerisi, fiyat primi, göreceli fiyat ve fiyat esnekliği takip etmiştir. Matrise ilişkin tutarsızlık oranı 0.09 olarak hesaplanmıştır. Bu oran ikili karşılaştırmaların tutarlı olduğunu göstermektedir.

Tablo 22. "Satış Kanalını Güçlendirmek" Stratejisine Göre Fiyat Ölçütlerinin İkili Karşılaştırması

\begin{tabular}{|l|l|l|l|l|l|l|}
\hline Fiyat Ölçütleri & FYÖ1 & FYÖ2 & FYÖ3 & FYÖ4 & FYÖ5 & $\begin{array}{l}\text { Yerel } \\
\text { Ağırlıklar }\end{array}$ \\
\hline Fiyat Esnekliği (FYÖ1) & 1 & $1 / 4$ & $1 / 3$ & $1 / 3$ & $1 / 5$ & 0.053 \\
\hline Fiyatlandırma Becerisi (FYÖ2) & & 1 & 5 & 5 & $1 / 2$ & 0.328 \\
\hline Fiyat Primi (FYÖ3) & & & 1 & 3 & $1 / 4$ & 0.128 \\
\hline Göreceli Fiyat (FYÖ4) & & & & 1 & $1 / 5$ & 0.079 \\
\hline Fiyatlandırma Tekniği (FYÖ5) & & & & & 1 & 0.413 \\
\hline
\end{tabular}

Çalışmada yer alan pazarlama performans ölçütlerinin genel ağırlıkları Tablo 23'de verilmiştir. Sıralama en fazla ağırlığa sahip olandan en az ağırlığa sahip olan pazarlama performans ölçütlerine doğru yapılmıştır.

Tablo 23. Pazarlama Performans Ölçütlerinin Genel Ağırlıkları

\begin{tabular}{|l|c|}
\hline \multicolumn{1}{|c|}{ Pazarlama Performans Ölçütleri } & $\begin{array}{c}\text { Genel } \\
\text { Ăğırlıklar }\end{array}$ \\
\hline Ürün Kalitesi & 0.195 \\
\hline Müşteri Memnuniyeti & 0.083 \\
\hline Ürün Bulunabilirliği & 0.072 \\
\hline Satış Süreci & 0.071 \\
\hline Satış Öncesi Süreç & 0.067 \\
\hline Yeni Ürün Konseptine Olan İnanç & 0.055 \\
\hline Müşteri Güveni & 0.049 \\
\hline Satışlar & 0.047 \\
\hline Fiyatlandırma Tekniği & 0.044 \\
\hline Fiyatlandırma Becerisi & 0.035 \\
\hline Pazar Payı & 0.033 \\
\hline Satış Sonrası Süreç & 0.033 \\
\hline Müşteri Sadakati & 0.030 \\
\hline Ürün Çeşitliliği & 0.027 \\
\hline Karlılık & 0.023 \\
\hline Yeni Ürün Sayısı & 0.022 \\
\hline Müşteri Yaşam Boyu Değeri & 0.018 \\
\hline
\end{tabular}




\begin{tabular}{|l|l|}
\hline Müşteri Etkileşim Süreci & 0.018 \\
\hline Fiyat Primi & 0.015 \\
\hline Yenilik Süreci & 0.014 \\
\hline Yeni Müşteri Sayısı & 0.013 \\
\hline Yatırımın Getirisi & 0.012 \\
\hline Göreceli Fiyat & 0.011 \\
\hline Fiyat Esnekliği & 0.007 \\
\hline Hissedar Değeri & 0.006 \\
\hline TOPLAM & 1.000 \\
\hline
\end{tabular}

\subsubsection{Performans Değerlendirme Ölçeğinin Belirlenmesi ve Değerlendirmenin Yapılması}

Çalışmanın bu bölümünde araştırma kapsamındaki işletmenin pazarlama performansının mevcut durumu değerlendirilmiştir. Performans değerlendirmesi için Yüksel ve Dağdeviren'in (2006) geliştirdiği ve Kömürcü'nün (2016) çalışmasına uyarladığı değerlendirme ölçeği kullanılmıştır. Ölçek altı seviyeden oluşmakta ve 0.0 ile 1.0 arasında değerlendirme yapmaktadır.

Tablo 24. Değerlendirme Ölçeği

\begin{tabular}{|l|l|}
\hline Mevcut Durum & Sayısal Değer \\
\hline Çok İyi (Ç) & 1.0 \\
\hline İyi (İ) & 0.8 \\
\hline Orta (O) & 0.6 \\
\hline Olumsuz (OZ) & 0.4 \\
\hline Çok Olumsuz (ÇOZ) & 0.2 \\
\hline Değerlendirmeye Giremez (DGZ) & 0.0 \\
\hline
\end{tabular}

Tablo 24'de yer alan değerlendirme ölçeği baz alınarak işletme yöneticisine modelde yer alan pazarlama performans ölçütlerinin mevcut durumuna ilişkin görüşleri sorulmuştur. Örneğin "işletmenizdeki karlılık ölçütünün mevcut durumunu nasıl değerlendirirsiniz?” sorusuna işletme yöneticisi “iyi” cevabını vermiştir. Yukarıda yer alan ölçeğe göre "iyi” değerlendirmesinin sayısal olarak karşıllı̆ı 0.8 'dir. Modelde yer alan diğer ölçütler içinde aynı soru yöneltilmiş ve işletme yöneticisi tarafından değerlendirme bu şekilde tamamlanmıştır. Tüm ölçütlerin değerlendirmesi yapıldıktan sonra Tablo 25 oluşturulmuştur.

Tablo 25. Önerilen Model ve Pazarlama Performans Ölçütlerinin Genel Değerlendirmesi

\begin{tabular}{|l|c|c|c|c|}
\hline \multicolumn{1}{|c|}{ Pazarlama Performans Ölçütleri } & $\begin{array}{c}\text { Genel } \\
\text { Ăğırlıklar }\end{array}$ & $\begin{array}{c}\text { Ölçütlerin } \\
\text { Mevcut } \\
\text { Durumu }\end{array}$ & $\begin{array}{c}\text { Mevcut } \\
\text { Durum } \\
\text { Değeri }\end{array}$ & $\begin{array}{c}\text { Ölçütlerin } \\
\text { Durum } \\
\text { Düzeyi }\end{array}$ \\
\hline Karlılık (FNÖ1) & 0.023 & $\dot{I}$ & 0.800 & 0.018 \\
\hline Satışlar (FNÖ2) & 0.047 & $\dot{I}$ & 0.800 & 0.038 \\
\hline Yatırımın Getirisi (FNÖ3) & 0.012 & O & 0.600 & 0.007 \\
\hline Pazar Payı (FNÖ4) & 0.033 & $\dot{I}$ & 0.800 & 0.026 \\
\hline
\end{tabular}




\begin{tabular}{|c|c|c|c|c|}
\hline Hissedar Değeri (FNÖ5) & 0.006 & $\mathrm{O}$ & 0.600 & 0.004 \\
\hline Müşteri Memnuniyeti (MŞÖ1) & 0.083 & Çİ & 1.000 & 0.083 \\
\hline Müşteri Sadakati (MŞÖ2) & 0.030 & İ & 0.800 & 0.024 \\
\hline Müşteri Yaşam Boyu Değeri (MŞÖ3) & 0.018 & İ & 0.800 & 0.014 \\
\hline Müşteri Güveni (MŞÖ4) & 0.049 & Çі் & 1.000 & 0.049 \\
\hline Yeni Müşteri Sayısı (MŞÖ5) & 0.013 & İ & 0.800 & 0.010 \\
\hline Satış Süreci (SRÖ1) & 0.071 & İ & 0.800 & 0.057 \\
\hline Satış Öncesi Süreç (SRÖ2) & 0.067 & İ & 0.800 & 0.054 \\
\hline Satış Sonrası Süreç (SRÖ3) & 0.033 & İ & 0.800 & 0.026 \\
\hline Yenilik Süreci (SRÖ4) & 0.014 & İ & 0.800 & 0.011 \\
\hline Müşteri Etkileşim Süreci (SRÖ5) & 0.018 & İ & 0.800 & 0.014 \\
\hline Yeni Ürün Sayısı (ÜRÖ1) & 0.022 & Çİ & 1.000 & 0.022 \\
\hline Ürün Bulunabilirliği (ÜRÖ2) & 0.072 & Çİ & 1.000 & 0.072 \\
\hline $\begin{array}{l}\text { Yeni Ürün Konseptine Olan İnanç } \\
\text { (ÜRÖ3) }\end{array}$ & 0.055 & İ & 0.800 & 0.044 \\
\hline Ürün Çeşitliliği (ÜRÖ4) & 0.027 & Çİ & 1.000 & 0.027 \\
\hline Ürün Kalitesi (ÜRÖ5) & 0.195 & Çİ & 1.000 & 0.195 \\
\hline Fiyat Esnekliği (FYÖ1) & 0.007 & $\mathrm{O}$ & 0.600 & 0.004 \\
\hline Fiyatlandırma Becerisi (FYÖ2) & 0.035 & İ & 0.800 & 0.028 \\
\hline Fiyat Primi (FYÖ3) & 0.015 & İ & 0.800 & 0.012 \\
\hline Göreceli Fiyat (FYÖ4) & 0.011 & $\mathrm{O}$ & 0.600 & 0.007 \\
\hline Fiyatlandırma Tekniği (FYÖ5) & 0.044 & İ & 0.800 & 0.035 \\
\hline \multicolumn{4}{|l|}{ TOPLAM } & 0.881 \\
\hline
\end{tabular}

Tablo 25'in birinci sütununda pazarlama performans ölçütleri, ikinci sütununda ölçütlerin genel ağırlıkları, üçüncü sütununda ölçütlerin genel durumu, dördüncü sütununda, ölçütlerin mevcut durumuna karş1lık gelen sayısal değerler, beşinci ve son sütununda ise ölçütlerin durum düzeyi yer almaktadır. Ölçütlerin durum düzeyi, genel ağırıklar ile mevcut duruma karşılık gelen sayısal değerin çarpılması ile bulunmuştur. Son satırda ise toplam performans düzeyi yer almıştır. Buna göre toplam değer 0.881 olarak hesaplanmıştır. Yani Tablo 25'e göre araştırma kapsamındaki bu işletmenin, çalışmada yer alan ölçütler dahilinde pazarlama performans düzeyinin $\% 88$ olduğu görülmüştür.

\section{SONUÇ VE ÖNERILLER}

Günümüzde pazarlama faaliyetlerinde hızla meydana gelen gelişmeler pazarlama yöneticilerini bu faaliyetlerin kontrolüne yönlendirmektedir. Pazarlama faaliyetlerinin kontrolünü sağlamak için bir ölçüm sistemi oluşturmak zor ve karmaşıktır. Çünkü doğru ölçümün nasıl gerçekleşeceği konusunda net bir bilgiye sahip olmak neredeyse imkansızdır. Bu nedenle performans değerlendirmede kullanılacak ölçüm kriterlerinin pazarlama faaliyetlerini bütünü ile yansıtacak nitelikte olması gerekir. Ayrıca sağlıklı bir ölçüm işletmelerin iç ve dış çevre analizleri sonucunda belirledikleri stratejiler doğrultusunda gerçekleşecektir.

Bu çalışma stratejik pazarlama performansını belirlemeye yönelik bir model önermektedir. Literatürde pazarlama performansı ile ilgili pek çok çalışma olmasına rağmen pazarlama stratejilerini baz alarak yapılan bir çalışmaya rastlanmamıştır. Çalışmanın diğer araştırmalardan bir diğer farkı ise, finansal, müşteri, süreç, ürün ve fiyat ölçütlerinin birlikte yer aldığı bir yaklaşımla değerlendirmenin yapılmasıdır. Ayrıca incelenen 
literatürde pazarlama performansının çok ölçütlü karar verme yaklaşımlarından herhangi biriyle değerlendirilmemiş olması da çalışmayı önemli kılan diğer bir unsurdur. Yani Analitik Hiyerarşi Prosesi, pazarlama performansının değerlendirilmesinde ilk defa bu çalışmada kullanılmıştır.

Çalışmada modelin tasarlanması dört aşamada gerçekleşmiştir. Birinci aşamada problem tespit edilmiştir. İkinci aşamada araştırma kapsamındaki işletmenin pazarlama yöneticisi ile görüşülerek, işletmenin iç ve dış çevre analizi ile vizyonları kapsamında belirledikleri pazarlama stratejileri öğrenilmiştir. Üçüncü ve dördüncü aşamada ise literatür taraması ve konuyla ilgili bilimsel çalışmalara sahip olan akademisyenlerin görüşleri sonucunda pazarlama performansının ölçülmesinde kullanılan bir ölçüt listesi oluşturulmuş ve ölçüt listesi nesnel bir yaklaşım izlenerek sınıflandırılmıştır. Böylelikle çalışmanın üçüncü ve dördüncü seviyesinde yer alan ana ve alt ölçütler belirlenmiştir. Model tasarlandıktan sonra pazarlama yöneticisi, stratejileri ve bu stratejiler doğrultusunda ana ve alt ölçütleri puanlamıştır. Yapılan puanlamanın ardından sonuçların tutarlı olduğu ve modelin geçerli olduğu kabul edilmiştir. Son olarak işletmenin pazarlama performans ölçütlerinin mevcut durumunun genel değerlendirmesi yapılmıştır. Genel değerlendirmenin sonucunda araştırma kapsamındaki işletmenin pazarlama performansının oldukça yüksek olduğu sonucuna varılmıştır.

Yazındaki pek çok çalışmada olduğu gibi bu çalışmada da finansal olmayan ölçütlerin pazarlama performansını belirlemede öncelikli olduğu görülmüştür. Özellikle ürün ölçütlerinden olan ürün kalitesinin diğer ölçütlere göre ağırlığı oldukça yüksektir. İncelenen literatürde genellikle müşteri memnuniyeti ve müşteri sadakati gibi ölçütlerin önem derecesi en yüksek iken ilk defa bu çalışmada kalite ölçütü birinci sırayı almıştır. Ürün kalitesini sırasıyla müşteri memnuniyeti, ürün bulunabilirliği ve satış süreci gibi ölçütler takip etmiştir. Çalışmanın en dikkat çekici yanı ise pazarlama performansının belirlenmesinde, literatürde genellikle önem derecesi yüksek bulunan karlılık, pazar payı gibi finansal ölçütlerin ağırlığının daha düşük olmasıdır. Bu durumun son yıllarda müşteri değerinin önem kazanması ve bu nedenle finansal olmayan ölçütlerin giderek değerinin artmasından kaynaklanmış olduğu söylenebilir. Ancak yine de pazarlama performansının değerlendirilmesinde finansal ölçütlerinde öneminin büyük olduğunu söylemek gerekir. Örneğin bir yıllık faaliyetlerinden kar elde etmeyen bir işletmenin gelecek yıldaki faaliyetleri için gerçekçi bir karar alması da imkansızdır. Ya da bir önceki yıla göre satışları artmamış, pazar payı büyümemiş bir işletmenin gerçek anlamda başarı elde ettiğini söylemek de doğru değildir. Bu nedenle ölçüm gerçekleşirken, faaliyet gösterilen sektöre, işletme türüne göre hatta işletmenin sahip olduğu fiziki imkanlardan, çalışan sayısına kadar her şeyi göz önünde bulundurup buna göre finansal ve finansal olmayan ölçütlerin belirlenmesi doğru olacaktır. Ancak bu şekilde sağlıklı bir ölçüm gerçekleşecek ve kesin sonuçlara ulaşılabilecektir. Ayrıca işletmenin iç ve dış çevre analizi sonrasında belirlediği stratejilerde performans değerlendirmede önemli bir faktördür. Çünkü bir işletme bu stratejiler doğrultusunda amaçlarına ulaşıp ulaşamadığını netleştirebilir.

$\mathrm{Bu}$ çalışmada mikro çevre faktörlerinden müşteri faktörü dikkate alınarak performans değerlendirmesi yapılmıştır. Diğer çalışmalarda tedarikçiler, rakipler, aracılar ve çalışan ölçütlerinin de dahil edildiği daha kapsamlı bir model oluşturulabilir. $\mathrm{Bu}$ çalışma üretim sektöründe faaliyet gösteren bir işletme ile gerçekleştirilmiştir. İleride yapılacak çalışmalar tarım ve hizmet sektöründe faaliyet gösteren işletmelerde yapılabilir. Böylece bu sektörlerde pazarlama performansı ölçülürken üretim sektöründen daha farklı olarak hangi ölçütlerden yararlanılması gerektiği ortaya konulabilir. Böyle bir çalışma sektörler arasında pazarlama performansının değerlendirilmesinde bir karşılaştırmaya da imkan verecektir. Bununla birlikte bu çalışmada Analitik Hiyerarşi Prosesi yönteminden yararlanıldığı için ölçütlerin ağırlıkları yukarıdan aşağıya doğru bir hiyerarşi şeklinde ele alınmıştır. Sonraki çalışmalarda Analitik Ă̆ Süreci (ANP) yönteminden yararlanılarak modeli oluşturan kriterler arasındaki etkileşimleri de göz önünde bulunduran bir çalışma yapılabilir. Ayrıca bu çalışmada pazarlama performansı için önerilen model, işletmelerin genel performansı ve finansal performans içinde uygulanabilir bir modeldir. Dolayısıyla hem yöneticiler hem de akademisyenler gelecekteki performans çalışmaları için uygun ölçütleri belirleyerek çalışmada önerilen modelden yararlanabilir. 


\section{KAYNAKÇA}

Ambler, Tim ve Flora Kokkinaki, (1997) "Measures of Marketing Success", Journal of Marketing Management, 5(13), s.665-678.

Ambler, Tim, (2000) "Marketing Metrics", Business Strategy Review, 11(2), s.59-66.

Ambler, Tim ve Wang Xiucun, (2003) "Measures of Marketing Success: A Comparison Between China and the United Kingdom", Asia Pacific Journal of Management, 20, s.267-281.

Ambler, Tim ve diğ., (2004) “Assessing Marketing Performance: Reasons for Metrics Selection”, Journal of Marketing Management, 20, s.475-498.

Aktepe, Adnan ve Süleyman Ersöz, (2014) "AHP-VIKOR ve MOORA Yöntemlerinin Depo Yeri Seçim Probleminde Uygulanması", Endüstri Mühendisliği Dergisi, 25(1-2), s.2-15.

Arslan, Elif, (2010) "Analitik Hiyerarşi Süreci Yöntemiyle Strateji Seçimi: Süleyman Demirel Üniversitesi İktisadi ve İdari Bilimler Fakültesinde Bir Uygulama", Süleyman Demirel Üniversitesi İktisadi ve İdari Bilimler Fakültesi Dergisi, 15(2), s.455-477.

Ataman-Akgül, Başak, (2004) “İşletmelerde Yeni Performans Ölçümleme Sistemleri”, Muhasebe ve Finansman Dergisi, 24, s.73-82.

Barwise, Patrick ve diğ., (2004) "Marketing Metrics: Status of Six Metrics in Five Countries", European Management Journal, 22(3), s.257-262.

Başkaya, Zehra ve Cüneyt Akar, (2005) "Üretim Alternatifi Seçiminde Analitik Hiyerarşi Süreci: Tekstil İsletmesi Örneği”, Sosyal Bilimler Dergisi, 1, s.273-286.

Bayraktaroğlu, Serkan ve diğ., (2014) "Kurumsal Kaynak Planlaması Başarısının Firmaların Algılanan ve Ölçülen Finansal Performansına Etkisinin İncelenmesi: Borsa İstanbul İmalat Sektörü Uygulaması”, Yönetim Bilimleri Dergisi, 12(23), s.277-299.

Beukes, Chris ve Gerhard Van Wyk, (2016) "An Investigation of the Marketing Performance Measurement Practices in Hatfield Volkswagen Group", African Journal of Business Management, 10(6), s.131-139.

Brooks, Neil ve Lyndon Simkin, (2011) "Measuring Marketing Effectiveness: An Agenda for SMEs", The Marketing Review, 11(1), s.3-24.

Bulut, Zeki At1l, (2013) "The Impact of Marketing Research Activities On Marketing Performance in Textile Companies: A Study in Denizli" Int. Journal of Management Economics and Business, 9(19), s.259-274.

Byun, Dae-Ho, (2001) “The AHS Approach For Selecting an Automobile Purchase Model”, Information\&Management, 38, s.289-297.

Clark, H. Bruce, (1999) "Marketing Performance Measures: History and Interrelationships”,Journal of Marketing Management, 15, s.711-732.

Clark, H. Bruce ve Tim Ambler, (2001) "Marketing Performance Measurement: Evolution of Research and Practice", International Journal of Business Performance Management, 3(2), s.1-23.

Clark, Bruce H., (2001) "A Summary of Thinking on Measuring the Value of Marketing", Journal of Targeting Measurement and Analysis for Marketing, 9 (4), s.357-369.

Cop, Ruziye ve Mustafa Bekmezci, (2008) "Değer Temelli Pazarlama Anlayışında Balanced Scorecard'ın Stratejik Önemi”, İ.Ü. Siyasal Bilgiler Fakültesi Dergisi, 39, s.247-266.

Çalık, Metin ve diğ., (2013) "Bütünleşik Pazarlama İletişimi, Marka Performansı Ve Pazar Performansı İlişkisinin İncelenmesi”, Uluslararası Yönetim İktisat ve İşletme Dergisi, 9(19), s.138-162.

Çatı, Kahraman ve diğ., (2012) "Otel İşletmelerinin Pazarlama Birimi Yapılarına Göre Performanslarının Değerlendirilmesi”, Ekonomik ve Sosyal Araştırmalar Dergisi, 8(8), s.23-42.

Çetin, Ayşe ve diğ., (2006) "Pazarlama ve Ürün Tasarımı Performansının Finansal Performans Üzerindeki Etkileri: İmalat Sektöründe Bir Uygulama", İktisat, İşletme ve Finans Dergisi, 9(3), s. 46-59.

Çıtak, Levent, (2015) "Pazarlama Yatırımlarının Finansal Performans Üzerindeki Etkisi ve Borsa İstanbul KOBİ Sanayi Endeksi Firmalarının Etkinliklerinin Değerlendirilmesi”, Erciyes Üniversitesi İktisadi Ve İdari Bilimler Fakültesi Dergisi, 45, s.49-68.

Dağdeviren, Metin ve diğ., (2004) "İş Değerlendirme Sürecinde Analitik Hiyerarşi Prosesi ve Uygulaması", Gazi Üniversitesi Mühendislik Mimarlık Fakültesi Dergisi, 19(2), s.131-138.

Dinçer, Hasan ve Ali Görener, (2011) "Performans Değerlendirmesinde AHP-VIKOR ve AHP-TOPSIS Yaklaşımları: Hizmet Sektöründe Bir Uygulama”, Sigma Mühendislik ve Fen Bilimleri Dergisi, 29(3), s.244-260.

Elisa, Rancati ve Niccolo Gordini, (2014) "Content Marketing Metrics: Theoretical Aspects and Empirical Evidence", European Scientific Journal, 10(34), s.92-104.

Ertuğrul, Murat, (2009) "Finansal Performans Ölçümünde Dönüşümlerin Türkiye Açısından Değerlendirilmesi”, Anadolu Üniversitesi Sosyal Bilimler Dergisi, 9(1), s.19-46.

Eusebio, Rossano ve diğ., (2006) "Measures of Marketing Performance: A Comparative Study from Spain" International Journal of Contemporary Hospitality Management, 18(2), s.145-155.

Farley, U. John ve diğ., (2008) "Marketing Metrics Use in a Transition Economy: The Case of Vietnam", Journal of Global Marketing, 21(3), s.179-190.

Gao, Yuhui, (2010) "Measuring Marketing Performance: A Reviewand a Framework", The Marketing Review, 10(1), s.25-40. 
Gaskill, Adam ve Hume Winzar, (2013) "Marketing Metrics That Contribute to Marketing Accountability in the Technology Sector", SAGE Journal, s.1-10.

Gronholdt, Lars ve Anne Martensen, (2006) "Key Marketing Performance Measures", The Marketing Review, 3, s.243252.

Günay, Burhan ve Hasan Ayyıldız, (2017) "Firmaların Pazarlama Faaliyet Performans Düzeylerinin Çok Kriterli Karar Verme Teknikleri İle Karşılaştırmalı Analizi”, Uluslararası İktisadi ve İdari İncelemeler Dergisi, 9(18), s. 113136.

Güner, Fatih M., (2006) “Stratejik Performans Değerlemede Dengeli Sonuç Kartı: Bir Sanayi İşletmesinde Uygulama”, Yayınlanmamış Doktora Tezi, Çukurova Üniversitesi, Sosyal Bilimler Enstitüsü, Adana.

Hacıoğlu, Güngör, (2010) "Pazarlama Performansının Değerlendirilmesi: Türk Firmalarında Pazarlama Performans Ölçütlerinin Kullanımı”, Yayınlanmamış Yüksek Lisans Tezi, Yaşar Üniversitesi, Sosyal Bilimler Enstitüsü, İzmir.

Hacıŏlu, Güngör, (2012) "Pazarlama Performans Ölçütleri: Bir Literatür Taraması”, Yönetim ve Ekonomi Dergisi, 19(1), s. 59-75.

Hacığlu, Güngör ve Osman Gök, (2013) "Marketing Performance Measurement: Marketing Metrics in Turkish Firms”, Journal of Business Economics and Management, 14(1), s.413-432.

Hooper, Anne Valerie, (2006) “ The Impact of the Alignment Between Unformation Systems and Marketing on Business Performance", Unpublished Doctoral Dissertation, Victoria Universty, Wellington.

Kabaday1, Ebru Tümer, (2002) "İşletmelerdeki Üretim Performans Ölçütlerinin Gelişimi, Özellikleri ve Sürekli İyileştirme İle İlişkisi”, Doğuş Üniversitesi Dergisi, 6, s.61-75.

Kapar, Kezban, (2013) "Bir Üretim İşletmesinde Analitik Hiyerarşi Süreci İle Tedarikçi Seçimi”, Dokuz Eylül Üniversitesi İktisadi ve İdari Bilimler Fakültesi Dergisi, 28(1), s.197-231.

Kara, Mehmet Akif ve Mehmet Seyhan, (2016) "Verimlilik Kavramı ve İşletmelerde Verimliliğin Önemi: AKFA Çay Fabrikası Örneği”, International Journal of Academic Value Studies, .2(3), s.161-169.

Knott, C. L. ve St. M. James, (2004) “An Alternate Approach to Developing a Total Celebrity Endorser Rating Model Using the Analytic Hierarchy Process", International Transactions in Operational Research, 11, s.87-95.

Kokkinaki, Flora ve Tim Ambler, (1999) "Marketing Performance Assessment: An Exploratory Investigation into Current Practice and the Role of Firm Prientation",Marketing Science Institute, Cambridge, MA, s.99-114.

Kömürcü, Kıvanç, (2016) “ İşletmelerde Stratejik Değerlemeye Yönelik Bir Model Önerisi”, Yayınlanmamış Yüksek Lisans Tezi, Kırıkkale Üniversitesi, Sosyal Bilimler Enstitüsü, Kırıkkale.

Mucuk, İsmet, (2014) Modern İşletmecilik, Türkmen Kitabevi Yayınları, İstanbul.

Milichovsky, Frantisek ve Iveta Simberova, (2015) "Marketing Effectiveness: Metrics for Effective Strategic Marketing”, Inzinerine Ekonomika-Engineering Economics, 26(2), s.211-219.

Mintz, Ofer ve S. Imran Currim, , (2013) "What Drives Managerial Use of Marketing and Financial Metrics and Does Metric Use Affect Performance of Marketing-Mix Activities?", Journal of Marketing, 77, s.17-40.

O’Sullivan, Don ve diğ., (2009) "Marketing Performance Measurement and Firm Performance: Evidence from the European High-Technology Sector”, European Journal of Marketing, 43(5/6), s.843-862.

Ömürbek, Nuri ve Ali Şimşek, (2014) “Analitik Hiyerarşi Süreci ve Analitik Ağ Süreci Yöntemleri Online Alışveriş Site Seçimi”, Yönetim ve Ekonomi Araştırmaları Dergisi, 22, s.306-327.

Ramadhan, Rezqallah H. ve diğ., (1999) “The Use Of an Analytical Hierarchy Process in Pavement Maintenance Priority Ranking", Journal of Quality in Maintenance Engineering, 5(1), s. 25-39.

Rust, Roland T. ve diğ., (2004) "Measuring Marketing Productivity: Current Knowledge and Future Directions", Journal of Marketing, 68, s.76-89.

Saaty, Thomas L., (1990) "How to Make a Decision: The Analytic Hierarchy Process", European Journal of Operational Research, 48, s.9-26.

Saaty, Thomas L., (2008) "The Analytic Hierarchy and Analytic Network Measurement Processes: Applications to Decisions under Risk", European Journal of Pure and Applied Mathematics", 1(1), s.122-196.

Sampaio, Hoffmann Claudio ve diğ., (2011) "Marketing Metrics: Insights from Brazilian Managers", Industrial Marketing Management, 40, s.8-16.

Smith, D. Shane ve J. Thomas Madden, (2005) "Marketing Metrics: A Push for Teaching the Value of Marketing as an Asset", Proceedings of the Annual Meeting of the Association of Collegiate Marketing Educators, s.217-227.

Toksarı, Murat ve Mehmet Mürütsoy, (2017) "Inbound Pazarlama Uygulamaları İle Pazarlama Performansı Arasındaki İlişkinin Ortaya Çıkarılmasına Yönelik Bir Araştırma”, İnsan Ve Toplum Bilimleri Araştırmaları Dergisi, 6(2), s.921-939.

Torlak, Ömer ve Remzi Altunışık, (2012) Pazarlama Stratejileri Yönetsel Bir Yaklaşım, Beta Yayınları, İstanbul.

Tüfekci, Kürşad Ömer ve Nezihe Tüfekci, (2014) "Pazarlama Yeniliği İle Pazarlama Performansı İlişkisini Açıklamaya Yönelik Bir Vaka Çalışması: Süleyman Demirel Üniversitesi Olimpik Yüzme Havuzu Örneği Ve Bir Model Önerisi”, Girişimcilik ve Kalkınma Dergisi, 9(1), s.162-182.

Uzkurt, Cevahir ve diğ., (2006) "İşletmeler İçin Pazar Bilgisi Yeteneğinin Önemi Ve Pazarlama Performansına Etkileri: 500 Büyük Firma Üzerinde Araştırma”, İ.Ü. İşletme Fakültesi Dergisi, 35, s.7-35. 
Uzun, Sümeyra ve Halim Kazan, (2016) “Çok Kriterli Karar Verme Yöntemlerinden AHP TOPSIS ve PROMETHEE Karşılaştırılması: Gemi İnşada Ana Makine Seçimi Uygulaması”, Journal of Transportation and Logistics, 1(1), s.99-113.

Vargas, Luis G., (1990) “An Overview of The Analytic Hierarchy Process and Its Applications”, European Journal of Operational Research, 48(1), s. 2-8.

Wang, H.S. ve diğ., (2010) "Using Analytic Hierarchy Process and Particle Swarm Optimization Algorithm for Evaluating Product Plans", Expert Systems with Applications, 37(2), s.1023-1034.

Wang, Ying-Ming ve diğ., (2008) "An Integrated AHP-DEA Methodology For Bridge Risk Assessment”, Computers \& Industrial Engineering, 54(3), s.513-525.

Yaralığlu Kaan, (2001) "Performans Değerlendirmede Analitik Hiyerarşi Prosesi”, D.E.Ü.İ.İ.B.F Dergisi, 16(1), s.129142.

Yaşar, Şebnem R., (2016) “Dengeli Puan Kartıyla Performans Ölçümü: Bir Denetim Şirketi Uygulaması”, Muhasebe ve Finansman Dergisi, 70, s.193-212.

Yeşildağ-Güven, Gül Nihan, (2016) "Mobil Pazarlama Uygulamalarının Pazarlama Performansı ve Müşteri Memnuniyetine Etkisi: Seyahat Acenteleri Üzerine Bir Araştırma", Yayınlanmamış Doktora Tezi, Beykent Üniversitesi, Sosyal Bilimler Enstitüsü, İstanbul.

Yiğiter, Şule, (2011) “İçsel Performans Göstergeleri ve Müşteri Memnuniyeti İlişkisi”, Akademik Bakış Dergisi, 23, s.1 17.

Yüksel, İhsan ve Metin Dağdeviren, (2006) "Sosyo-Teknik Sistemlerde Hatalı Davranış Riskini Belirlemeye Yönelik Bir Erken Uyarı Modeli”, Gazi Üniversitesi Mühendislik Mimarlık Fakültesi Dergisi, 21(4), s.791-799.

Zahay, Debra ve Abbie Griffin, (2010) "Marketing Strategy Selection, Marketing Metrics and Firm Performance", Journal of Business \&Industrial Marketing, 25(2), s.84-93. 